\title{
Aloe Plant Extract as Environmentally Friendly Inhibitor on the Corrosion of Aluminum in Hydrochloric Acid in Absence and Presence of Iodide Ions
}

\author{
A. M. Al-Turkustani \\ King Abd El-Aziz University, Girls College of Education, Chemistry Department, Jeddah, KSA \\ E-mail: A.M.Turkustani@hotmail.com
}

S. T. Arab

King Abd El-Aziz University, Girls College of Education, Chemistry Department, Jeddah, KSA

E-mail: prof.s.t.arab@hotmail.com

R. H. Al-Dahiri

King Abd El-Aziz University, Girls College of Education, Chemistry Department, Jeddah, KSA

E-mail: r.h.208@hotmail.com

\begin{abstract}
The study shows that the corrosion of Aluminum increases with increasing $\mathrm{HCl}$ concentration which indicates the dependence of Aluminum corrosion on the concentration of $\mathrm{HCl}$.The inhibition efficiency of the corrosion by $\boldsymbol{A l o e}$ extract was found to increase with the increase of $\boldsymbol{A l o \boldsymbol { e }}$ extract concentration. Its inhibitive action from chemical (hydrogen evolution and mass loss) and electrochemical (polarization and impedance) was in good agreement. Also, it was found that Aloe plant act as mixed type inhibitor. The corrosion of Aluminum is mainly controlled by a charge transfer process. The inhibition action occurred through the adsorption of the extract on Aluminum surface, the adsorption process follows Freundlish adsorption isotherm. The addition of iodide ions enhances the inhibition efficiency for Aloe plant extract.
\end{abstract}

Keywords: Corrosion, Corrosion inhibitor, Aluminum, Acid corrosion, Aloe plant inhibitor

\section{Introduction:}

Many important applications of Aluminum and its alloys have resulted in researches due to its electrochemical behavior and corrosion resistance in a wide variety of media, including investigation of the properties of the surface oxide film formed naturally or by iodization (G. Warnglen, 1985). Aluminum has high resistance to corrosion in many environments; this is attributed to a protective surface film formed rapidly in air or in neutral aqueous solutions, which is preserved even after long periods of immersion in acidic and alkaline media (M. Hurovic, R. Babic, Z. Grubac and S. Brinic, 1994), and in nearly neutral aqueous solutions (C. Brett, I. Gomes and J. Marhins, 1994).

Hydrochloric acid solutions are normally used for pickling of Aluminum and for its chemical and electrochemical etching to corrosion (E. E. Oquzic, G. N.Onuoha and E. N. Ejibe, 2007).

Efforts have been made to ameliorate the Aluminum surface film dissolution and hence protect the integrity of the metal in aggressive acid medium. One of the most important methods is the use of inhibitors to hinder the corrosion reaction and thus reduce the corrosion rate.

Investigations have been made recently into the corrosion inhibiting properties of natural products of plant origin, which was found to exhibit good inhibition efficiencies (F. Zucchi, I. H. Omar, 1985)(M. Kliskic, J. Radosevic, S. Gudic and V. Katalinik, 2000)(A. Y. El-Eter, 2003)(M. Abdallah, 2004)( E. E. Oquzic, 2006). The use of natural products for metals protection is of much importance because in addition to being inexpensive, readily available and renewable sources of materials, plant products are environmentally friendly and ecologically acceptable.

Aloe plant extract is organic in nature and can be use in the production of green inhibitor and it is one of natural inhibitor which has an inhibitive action on the corrosion of metals. Aloe Vera gel is the colorless mucilaginous gel obtained from the parenchymaous cell in the fresh leaves of Aloe Vera. It contains of various active 
compounds such as: salicylates, magnesium lactate, acemennan, lupeol, campestrol, sterol, linolenic, aloctin and anthraquinones (T. Blitzke, A. Porzel, M. Masaoud and J. Schmidt, 2000).

In this study, chemical and electrochemical methods are applied to study the corrosion behavior of Aluminum in hydrochloric acid. The inhibition efficiency of Aloe extract as natural inhibitor for the corrosion of Aluminum in $0.5 \mathrm{M} \mathrm{HCl}$ and the effect of iodide ions were studied. SEM was applied for surface morphology to confirm the obtained results.

\section{Experimental}

\subsection{Specimen}

The composition of the Aluminum sample used in these exponents is given in Table (1)

\subsection{Surface Pre-treatment:}

Before all measurements the specimen was polished first with a series of emery paper of type (231 Qwetordry Imperical Paple aesoc), starting with a coarse one and proceeding in steps to find grade. Then the sample was thoroughly washed with deionised water then with acetone (A.R), dried by stream of air. The sample was then immediately immersed in the test solution.

\subsection{Solutions:}

Hydrochloric acid and NaI (Fluka) were used. All solutions were prepared with analytical grade reagents (A.R.). Deionised water was used throughout for the preparation of solutions.

Stock solution of Aloe plant leaves extract was prepared by extracting $0.5 \mathrm{~kg}$ Aloe leaves in water and boiled for some time then mixed in a plinder. The solution was cooled and filtered by air bump and then the filtered solution was kept at low temperatures.

From the respective stock solutions, the inhibitor test solutions were prepared in the concentration range $(4-60) \% \mathrm{v} / \mathrm{v}$. The concentration range of NaI employed was $\left(1.0 \times 10^{-4}-5.0 \times 10^{-2}\right) \mathrm{M}$. For the inhibition study $0.5 \mathrm{M} \mathrm{HCl}$ was used.

\subsection{Techniques:}

\subsubsection{Chemical measurements:}

The chemical measurements were carried out by two methods; hydrogen evolution method (HEM) and mass loss method (MLM) using a vessel which has the same form as that described by Mylius (F. Mylius and S. Niethem, 1957). The effect of hydrochloric acid concentration at $(0.25,0.5,0.75,1.0,1.25$ and $1.5 \mathrm{M})$ on the corrosion of Aluminium at $30^{\circ} \mathrm{C}$ was studied. Also, the effect of Aloe extract at different concentrations was studied in absence and presence of $\mathrm{I}^{-1}$ at $0.5 \mathrm{M} \mathrm{HCl}$ solutions.

\subsubsection{Electrochemical measurements:}

Two kinds of measurements; potentiodynamic polarization (PDP) and impedance (EIS) measurements were carried out using an impedance spectrum analyzer (ACM instrument) connected to a Samsung computer (Bridgemax DVD ASUS 8X) (S. T. Arab and A. M. Al-Tukustani, 2002). Electrochemical impedance spectroscopy (EIS) measurements were conducted in dearated $\mathrm{HCl}$ solutions of different concentrations at open-circuit (O.C) conditions.

\subsubsection{Scanning Electron Microscopy (SEM) Analysis:}

SEM analysis of the electrode surface was carried out using Scanning Electron Microscopy XL 20 PHILPS. The magnification varied from 10x up to 500x.

\section{Result and discussion}

\subsection{Effect of the hydrochloric acid concentration at $30^{\circ} \mathrm{C}$ : \\ a- Chemical study:}

Figure (1) shows the plots of hydrogen volume with time, the increase in rate of hydrogen evolution depend on the acid concentration. As the concentration of the $\mathrm{HCl}$ solution increases, the slop of the straight lines also increases, indicating an increase in the dissolution of Aluminum, e.g. increases of corrosion rate. An induction period was observed especially at low concentrations of $\mathrm{HCl}$ due to the slow reaction between the acid and the air formed oxide film on Aluminum surface as reported before (K. Srivastava and P. Srivastava, 1981)(P. S. Khosla, J. B. Singh and R. K. Srivastava, 2000). The induction period decreases with increasing acid concentration. The presence of oxide film leads to blocking the surface of the Aluminum and prevent the solution reaching the metal surface, the oxide film causes the corrosion rate to decrease (A. A. Mazhar, S. T. 
Arab and E. A. Noor, 2001). The variation in the induction period was explained to be either to the $\mathrm{HCl}$ concentration increase or time needed for penetration of $\mathrm{Cl}^{-}$through the oxide film and make it destruction, then the dissolution of Aluminum will occur (E. Oquzic, 2007)(A. M. Al- Mayouf, 1996).

At high concentrations of $\mathrm{HCl}$ solution, the attack on oxide film by chloride ions was instantaneous and very quick, and $\mathrm{Cl}^{-}$ions will accelerate the corrosion reaction by retarding film repair and forming intermediate soluble complex as follows (R. Ambat and E. S. Dwarakadasa, 1993):

$\mathrm{Al}+\mathrm{n} \mathrm{Cl}^{-} \rightarrow \mathrm{AlCl}_{\mathrm{n}}^{(\mathrm{n}-3)}+3 \mathrm{e}^{-}$

The formed complexes facilitate the dissolution of the Aluminum ions (or atoms) from the lattice into the solution and leads to local thinning of the passive layer on the metal surface and to pitting (localized) corrosion. This illustrates that, as the immersion time increases, the hydrogen evolved by constant rate (especially at 1.0 $\mathrm{M}$ and $1.25 \mathrm{M}$ of $\mathrm{HCl}$ ), this may be explained as that, the formation of insoluble complex will adsorbed on Aluminum surface or due, to existence of thin oxide film formed before immersion and hindrance the solution diffusion to Aluminum surface.

The corrosion rate, R, from HEM in $\left(\mathrm{ml} . \mathrm{cm}^{-2} \mathrm{~min}^{-1}\right)$ as well as, the corrosion rate obtained from MLM is calculated from the simple relationship $\mathrm{R}^{\prime}=\mathrm{dw} / \mathrm{dt}$ in $\left(\mathrm{g} . \mathrm{cm}^{-2} \mathrm{~min}^{-1}\right)$ where $\mathrm{dw}$ is the mass loss and $\mathrm{dt}$ is the immersion time.

Table (2) illustrates the corrosion rate ( $\mathrm{R}$ and $\mathrm{R}^{\prime}$ ) values for Aluminum in $\mathrm{HCl}$ solutions from HEM and MLM, respectively. It was found that, the corrosion rate increases with the increase of $\mathrm{HCl}$ concentration; this indicates that Aluminum corrosion in $\mathrm{HCl}$ is concentration dependent. Corrosion of Aluminum in aqueous solution has been reported (A. M. Al- Mayouf, 1996)(T. H. Nguyen and R. T. Foley, 1982) to depend on the concentration of anions in solution.

Figure (2) shows the variation of $\log \mathrm{R}$ and / or $\log \mathrm{R}$ ' with $\log \mathrm{C}$ of $\mathrm{HCl}$ solutions for Aluminium at $30^{\circ} \mathrm{C}$. It was obvious that, the slopes of the straight lines equal to 3.04 and 3.06, respectively, this means that the degree of the reactions between Aluminium and $\mathrm{HCl}$ is a third order reaction, by applying the relation:

$\log \mathrm{R}=\log \mathrm{A}+\mathrm{n} \log \mathrm{C}$

The first step in the pitting process is suggested to be, the adsorption of chloride ion $\left(\mathrm{Cl}^{-}\right)$on the oxide covered Aluminium surface. When $\mathrm{Cl}^{-}$, interacts with an ionic surface, such as an oxide, the attractive forces consist of (E. Mc Caffety, 2003): (i) columbic forces, (ii) induction of the adsorbent by the approaching ion, (iii) electrostatic polarization of the ion and (iv) non-polar van der Waals forces (J. H. de Boer, 1950). Of these attractive forces, the largest are the first two interactions, which are ionic.

A general mechanism for the dissolution of Aluminium metal in aqueous solutions would be similar to that reported by Ford et al. (F. P. Ford, G. T. Burstein and T. P. Hoar, 1980) as well as Nguyen and Foley (T. H. Nguyen and R. T. Foley, 1982):

$\mathrm{Al}_{(\mathrm{s})}+\mathrm{H}_{2} \mathrm{O} \leftrightarrow \mathrm{AlOH}_{\mathrm{ads}}+\mathrm{H}^{+}+\mathrm{e}^{-}$

$\mathrm{AlOH}_{\mathrm{ads}}+5 \mathrm{H}_{2} \mathrm{O}+\mathrm{H}^{+} \leftrightarrow \mathrm{Al}^{+3}+6 \mathrm{H}_{2} \mathrm{O}+2 \mathrm{e}^{-}$

$\mathrm{Al}^{+3}+\mathrm{H}_{2} \mathrm{O} \leftrightarrow[\mathrm{AlOH}]^{+2}+\mathrm{H}^{+}$

$[\mathrm{AlOH}]^{+2}+\mathrm{X}^{-} \leftrightarrow[\mathrm{AlOHX}]^{+}$

The controlling step in the metal dissolution is the complexation reaction between the hydrated cation and the anion present (eq. (6)). In the presence of chloride ions the reaction will correspond to:

$[\mathrm{AlOH}]^{+2}+\mathrm{Cl}^{-} \leftrightarrow[\mathrm{AlOHCl}]^{+}$

Since the reaction obtained have third order, thus the soluble complex $[\mathrm{AlOHCl}] \mathrm{Cl}$ will formed as:

$[\mathrm{AlOH}]^{+2}+2 \mathrm{Cl}^{-} \leftrightarrow[\mathrm{AlOHCl}] \mathrm{Cl}$

The soluble complex ion formed increases the metal dissolution at a rate which depends on the chloride concentration, this accounts for the observed increase in corrosion rate as the concentration of $\mathrm{HCl}$ is increased.

b- Electrochemical study:

Figure (3) shows the anodic and cathodic polarization curves of Aluminium in $\mathrm{HCl}$ solution at different concentrations. It was shown that, the increase of concentration of the acid leads to displacement the anodic and cathodic curves to high current densities and increase the corrosion rate will be found, Table (3). At higher concentrations of acid, the anodic polarization curves give small hump depending on the concentration of the acid, which is associated with the formation of an adsorbed thin layer on Aluminium surface or thin layer from 
non-porous oxide film leads to minimise the passing current to Aluminium surface. Results of electrochemical parameters, $E_{\text {corr. }}, I_{\text {corr. }}$ and Tafel constants $\left(b_{a} \& b_{c}\right)$ obtained from these curves are listed in Table (3).

It obvious from Fig. (3) and Table (3) that the increase in acid concentration lead to displacement in anodic and cathodic curves to high values of current density and increase in corrosion rate.

-At high $\mathrm{HCl}$ concentrations, e.g. $(0.75,1.0,1.25$ and $1.5 \mathrm{M})$ and high potential, a more or less passive region is detected during anodic polarization, which indicates onset of localized attack (pitting corrosion). The passive region may be attributed to existence of the air formed an oxide film on the metal surface (B. R. Baker and J. D. Balser, 1976). These were confirmed by chemical measurements (HEM).

- The values of $\mathrm{E}_{\text {corr. }}$ shift to more negative values with increase in $\mathrm{HCl}$ concentration.

Figure $(4(a, b))$ show the dependence of $\mathrm{E}_{\text {corr. }}$ and $\mathrm{I}_{\text {corr. }}$ on acid concentration. The linear relation in case of $\mathrm{E}_{\text {corr }}$, Fig. (4a), can be represented by the equation (A. M. Beccaria and G. Poggi, 1986):

$\mathrm{E}_{\text {corr. }}=\mathrm{E}_{\text {corr. }}+(2.303 \mathbf{R T} / \mathrm{n} \mathrm{F}) \log \mathrm{C}$

Where $E_{\text {corr. }}$ is the corrosion potential when the acid concentration is equal to unity, $\mathbf{R}$ is the universal gas constant, $\mathrm{T}$ is the absolute temperature, $\mathrm{n}$ is the number of electrons, $\mathrm{F}$ is the Farad and $\mathrm{C}$ is the concentration, it is found that the value of $\mathrm{E}_{\text {corr. }}=-795.0 \mathrm{mV}$ and $\mathrm{n}=1.38 \times 10^{-3}$. The deviation of $\mathrm{n}$ from the expected value may be related to a multi-step process of oxide film protection. Figure (4b) also, illustrate the relation between $\mathrm{I}_{\text {corr. }}$ and concentration follows the relation:

$\mathrm{I}_{\text {corr. }}=\mathrm{a}+\mathrm{b} \log \mathrm{C}$

where $\mathrm{a}$ and $\mathrm{b}$ are characteristics dependent on the corroding surface.

From Fig.(4) it can be seen that, both $\mathrm{E}_{\text {corr. }}$ and $\mathrm{I}_{\text {corr. }}$ obey linear relation with $\mathrm{HCl}$ concentration with correlation constants equal to 92.5 and 98 , respectively.

Figure (5) shows the Nyquist plots of the studied Aluminum sample in $\mathrm{HCl}$ solutions at $30^{\circ} \mathrm{C}$. It is seen from the figure that the impedance diagrams in most cases are not a perfect semi-circle, and this difference has been attributed to frequency dispersion. The semi-circle appearance indicates that the corrosion of Aluminium sample is mainly controlled by the charge transfer process, and it appears that there is a decrease in polarization resistance $R_{p}$ values as judged from the decrease in the diameters of the semi-circles with increasing in $\mathrm{HCl}$ concentration to the dissolved of oxide film formed on Aluminium surface. The high frequency capacitive semi-circle is related to the dielectric properties and thickness of the oxide film (F. Zucchi, I. H. Omar, 1985), while the incomplete inductive loop may indicate to the presence of at least one adsorbed species (T. U. Chavanin, 1991), or the occurrence of localized corrosion (F. Zucchi, I. H. Omar, 1985). It is also seen that an inflection appears in the semi-circle especially at high $\mathrm{HCl}$ concentrations, which indicate the presence of an adsorbed film or localized attack, as previous observation.

At low concentrations of $\mathrm{HCl}(1.0$ and 1.25$) \mathrm{M}$, the passive oxide film locally ruptures and heals spontaneously as proved by A.C. impedance measurements (A. El-Etre, M. Abdullah and Z. El-Tantawy, 2005), while at higher concentrations $(1.5 \mathrm{M})$ prevent the healing process. This supports the motion that $\mathrm{Cl}^{-}$ions responsible for the attack of the film and subsequent dissolution of the oxide layer, this appears from Fig.(1) in chemical measurements.

This in agreement with the study of Brett (C. N. A. Brett, 1990) by EIS technique. It was suggested that in the corrosion behavior of Aluminum in $0.1 \mathrm{M} \mathrm{HCl}$ the spectra indicates that the electrochemical processes in passive region are mainly controlled by a multi-step dissolution, ionic migration through the oxide layer and the influence of $\mathrm{Cl}^{-}$ions. This behavior is similar to that obtained from polarization and HEM results.

Electrochemical parameters $\left(\mathrm{R}_{\mathrm{ct}}\right.$ and $\left.\mathrm{C}_{\mathrm{dl}}\right)$ established from Nyquist diagram are listed in Table (3). As can be seen from this Table, the charge transfer resistance $\left(\mathrm{R}_{\mathrm{ct}}\right)$ for Aluminum sample in $\mathrm{HCl}$ solutions decreases with $\mathrm{HCl}$ concentration increase, and the $\mathrm{C}_{\mathrm{dl}}$ values increased, this may be due to the formation of oxide-chloride complexes, or the adsorbed complex [AlOHCl] $\mathrm{Cl}$ on the surface of Aluminum (E. Marboe and S. Bentur, 1961).

According to the mechanism proposed by Marbo and Bentur (E. Marboe and S. Bentur, 1961), $\mathrm{O}^{-2}$ ions are also formed in the solid phase by top chemical reaction. Consequently, $\mathrm{Al}\left[\mathrm{O}_{\mathrm{x}}(\mathrm{OH})_{y}\left(\mathrm{H}_{2} \mathrm{O}\right)_{z}\right]$ is the idealized formula for the solid hydroxo complexes.

The presence of aggressive ions like $\mathrm{Cl}^{-}$prevent the formation of the passive film and accelerates the process of anodic dissolution, the more the greater is the concentration of $\mathrm{Cl}^{-}$ions. The pitting corrosion of Aluminum is due to the migration of chloride ions through the oxide film or due to the chemisorbed $\mathrm{Cl}^{-}$onto the oxide surface 
where they act as the reaction partners, aiding dissolution via the formation of different mixed oxo-hydro- and chloro- complexes.

Analysis of the polarization and impedance curves show that no passive active transition up to high current was observed. Anodic dissolution of the metal does occur at appreciable rate in solutions containing aggressive anions, particularly chloride.

\subsection{Corrosion inhibition of Aluminum in $0.5 \mathrm{M} \mathrm{HCl}$ at different concentrations of Aloe plant extract at $30^{\circ} \mathrm{C}$.}

The polarization curves (Fig. (6)) show the effect of aqueous extract of Aloe plant in the concentration range (4-60) $\% \mathrm{v} / \mathrm{v}$ on the corrosion of Aluminium in $0.5 \mathrm{M} \mathrm{HCl}$. It can be seen that, Aloe extract retarded the cathodic (hydrogen evolution) and the anodic (Aluminium dissolution) reactions, i.e., the increase of the Aloe extract concentration cause the displacement of the curves, this was more pronounced in the cathodic curves, thus the cathodic sites are blocked to a greater extent than the anodic sites by the extract components (A. M. Mohamed, A. Al- Nadjm and A. A, Fouda, 1998). This means that the Aloe extract act as mixed inhibitor mainly cathodic inhibitor. Also, the increase of Aloe extract concentrations cause gradual lowering in current density and corrosion rate values.

It is obvious from the relation between $\mathrm{I}_{\text {corr. }}$ and $\log \mathrm{C}_{\text {inh. }}$ (Fig.(7)) that the increases in Aloe extract concentration lead to lowering $\mathrm{I}_{\text {corr. }}$ values which indicate the high ability of Aloe extract to inhibit the dissolution of Aluminium in $\mathrm{HCl}$ solution.

The percentage inhibition efficiency (Inh.\%) was calculated using the equation:

Inh. $\%=\left[I_{\text {corr.add. }} / \mathrm{I}_{\text {corr.free }}\right] \times 100$

where $\mathrm{I}_{\text {corr.free }}$ and $\mathrm{I}_{\text {corr.add. }}$ are the corrosion current densities in the absence and presence the extract, respectively.

Table (4) shows the corrosion kinetics parameters, $b_{a}, b_{c}, E_{\text {corr. }}, R_{\text {corr. }}$ and Inh.\%, the following observation could be drawn :

1) The anodic $\left(b_{a}\right)$ and cathodic $\left(b_{c}\right)$ Tafel slopes were changed in irregular form, this observation was previously recorded in many studied especially for Aluminium (M. Abdlallah, 1981)(A. Fouda, H.

El-Nadar and M. Moussa, 1987)( A. Mohamed, T. Rakha, M. Moussa, 1990)( A. Bouyanzer and B. Hammouti, 2004)( M. M. Saleh, 2006).

2) The values of $E_{\text {corr. }}$ change slowly to less negative values more positive (i.e., nearly remain constant) and the values of $\mathrm{I}_{\text {corr. }}$ decrease. This indicates that Aloe plant primarily cause anodic polarization (M. Abdallah, Bull, 2000).

3) The values of Inh.\% increases, indicating the inhibiting effect of Aloe plant at all concentrations except at the low concentration $(4 \% \mathrm{v} / \mathrm{v})$ it gives acceleration. This indicates that the inhibition efficiency depends upon the concentration of Aloe extract.

The inhibitive behavior could be attributed due to the adsorption of Aloe components on the Aluminium surface. The increase of the surface coverage $(\Theta)$ is found as the extract concentration increased. Competitive adsorption is assumed to occur on the surface of the metal between the aggressive $\mathrm{Cl}^{-}$and the Aloe components at low concentrations, and the limited coverage leads to pitting corrosion which increase the rate of corrosion and acceleration will occur (V. Branzoi, F. Golgovici and F. Branzoi, 2002).

In order to get more information about the corrosion which increase inhibition phenomenon, solution resistance $\left(\mathrm{R}_{\mathrm{s}}\right)$, polarization resistance $\left(\mathrm{R}_{\mathrm{p}}\right)$, double layer capacitance $\left(\mathrm{C}_{\mathrm{dl}}\right)$ and charge transfer resistance $\left(\mathrm{R}_{\mathrm{ct}}\right)$ of Aluminium sample, impedance measurements have been carried for the Aluminium sample in $0.5 \mathrm{M} \mathrm{HCl}$ in the absence and presence of different concentrations of the aqueous extract of Aloe plant.

Figure(8) shows the effect of Aloe extract concentration on the impedance response of Aluminium sample in $0.5 \mathrm{M} \mathrm{HCl}$ dearated solution at open circuit potential (OCP), after immersion of 15 minutes. The locus of the Nyquist plots was regarded as one part of a semicircle. The data reveal that the impedance diagrams in most of the cases is not a perfect sime-circle and this has been attributed to frequency dispersion and the half circle indicates that the corrosion of Aluminium is mainly controlled by the charge transfer process and the presence of Aloe extract in solution does not affect the mechanism of dissolution of Aluminium (F. Mansfeld, M. W. Kending and S. Tasi, 1980)(F. Mansfeld, M. W. Kending and S. Tasi, 1982). The charge transfer resistance $\mathrm{R}_{\mathrm{ct}}$ has been calculated using Stern-Geary equation to get corrosion current from the difference in impedance at lower and higher frequencies as suggested by Tsura et al. (T. Tsura, S. Haruyama and B. Gijutsu, 1978)

For the calculation of double layer capacitance $C_{\mathrm{dl}}$, the frequency at which the imaginary component of the impedance $Z^{\prime \prime}$ is maximum i.e., $\left(Z^{\prime \prime}{ }_{\max }\right)$ is found and the double layer capacitance values are obtained from the relationship: 
$f\left(-Z_{\text {max }}^{\prime \prime}\right)=1 / 2 \pi \mathrm{C}_{\mathrm{dl}} \mathrm{R}_{\mathrm{ct}}$

Electrochemical chemical parameter $\mathrm{R}_{\mathrm{sol}}, \mathrm{R}_{\mathrm{ct}}$ and $\mathrm{C}_{\mathrm{dl}}$ established from the Nyquist diagram, obtained without and with the addition of different concentrations of Aloe extract in $0.5 \mathrm{M} \mathrm{HCl}$ solution, are listed in Table (4). It is seen from this table that the increase in the concentration of the Aloe extract increases the value of $\mathrm{R}_{\mathrm{ct}}$ and decreases the corrosion of Aluminium in $0.5 \mathrm{M} \mathrm{HCl}$ solution and considerably reduced due to the adsorption of the Aloe component on Aluminium surface, or due to the increasing surface coverage by the Aloe molecules which leads to an increase in the inhibition efficiency with increasing Aloe plant concentration.

The inhibition efficiency of the corrosion of Aluminium is calculated as follows:

Inh. Rct $\%=\mathrm{R}_{\text {cto }}{ }^{-1}-\mathrm{R}_{\mathrm{ct}}{ }^{-1} / \mathrm{R}_{\text {cto }}{ }^{-1} \times 100$

Where $\mathrm{R}_{\mathrm{cto}}$ and $\mathrm{R}_{\mathrm{ct}}$ are the values of charge transfer resistance without and with Aloe extract respectively. The values of inhibition efficiencies calculated are listed in Table (4).

It can be seen that the results of impedance studies are less in agreement with those obtained from polarization techniques, this attributed to that in the polarization process the clean of surface of Aluminium electrode will occurred as a result to beginning the cathodic polarization and the anodic polarization, this reduction cause the surface of Aluminium free from any adsorbed oxides.

-Adsorption Isotherm:

The decrease in the corrosion rate by the addition of Aloe extract is attributed to the adsorption of these extract molecules on the metal surface or to the formation of barrier film separating between the metal surface and the corrosion medium (B. K. Gary, R. A. V. Raff and R. V. Subramanian, 1977)(S. Rengamanmi, S. Muralidharan, M. Anbu Kulandainathan and S. U. Iyer, 1994).

The process of adsorption can be described by two main types of interaction: physical adsorption and chemical adsorption. These are influenced by the nature and charge of the metal, extract composition and the type of electrolyte (F. Bentiss, M. Lagrenee, M.Traisnel, B. Mernani and H. Elattari, 1999).

The aqueous extract of Aloe plant investigated in this study is organic in nature and contain anthraquinones, coumarins and reducing substances. The constituents of Aloe extract are mostly composed of oxygen containing compounds. Adsorption of these constituents may occur through their oxygen active centres. Moreover, these compounds may also form complexes with metallic cations. The complexes can cause blocking of the micro anodes and / or the micro cathodes that are generated on the Aluminium surface when in contact with accordant $(\mathrm{HCl})$, and hence can retard the dissolution of the Aluminium (M. Quraishi, I. Farooqi and P. Saini, 1999).

In hydrochloric acid, Aloe compounds forms its hydrochloride, or more specifically, it exists as a moiety of protonated Aloe or Aloe compounds ions and chloride ion (G. Banerjee and S. N. Malhotra, 1992). When Aluminum electrode is immersed in dilute solution of hydrochloric acid containing Aloe, three kinds of species can be adsorbed on its surface, which are described as (G. B. Hunt and A. K. Holiday, 1980):

-If the metal surface is positively charged (with respect to potential of zero charge (PZC)), the chloride ions will first be adsorbed on the metal surface, which in turn will attract the Aloe compounds ions and protonated water molecules. Therefore, a close-packed triple layer will form on the metal surface and inhibit Aluminium ions to enter the solution. Hence, with an increase in the positive charge on the metal surface, the adsorption of Aloe would increase and the Aloe content of the solution would decrease.

-If the metal surface is negatively charged with respect to PZC, the protonated water molecules and the Aloe compounds ions would be directly adsorbed on the metal surface. With increasing the negative charge on the metal surface, adsorption of Aloe increase and its concentration in solution would decrease.

-When the metal surface attains the potential at which the surface charge becomes zero, none of the ions (neither cations nor anions) adsorb on the surface through their centres. A few Aloe compounds molecules may however be physically adsorbed through their planar $\pi$ orbitals on the metal surface (with vacant $d$ orbitals). Because of this possibility, the concentration of Aloe in solution at PZC also decreases instead of remaining the same. However, the decrease is small due to the fact that, in the case of planar adsorption, the molecular density of Aloe on the Aluminium surface becomes smaller to a lesser degree than in the case of later-ionic adsorption. The amount of Aloe adsorbed is smaller in the former case than in the latter.

Figure (9) shows the variation of the protection efficiency from the polarization and impedance methods with the logarithm of the concentration of Aloe extract at $\mathbf{3 0}^{\circ} \mathbf{C}$. The plots show that the Aloe extract inhibits the corrosion of Aluminium and the inhibition efficiency increased with the increase in the extract concentration. These results suggest that the inhibitor retard the dissolution of Aluminium by adsorption of Aloe molecules at 
Aluminium $\backslash$ acid solution interface. One inflection point was observed, indicating perhaps that the Aloe extract form a monolayer on the surface of Aluminium.

The adsorption of Aloe molecules on the Aluminium surface was found to follow the Freundlish adsorption isotherm (Fig.(10)) which is given by (B. Berge, K. Grijotheim, C. Kronhn, R. Ncumann and K. Torkiep, 1976)(M. Kliskic, J. Radosevic, S. Gudic and V. Katalinik, 2000):

$\Theta=\mathrm{KC}^{\mathrm{n}}$

where $0<\mathrm{n}<1$

$\log \Theta=\log \mathrm{K}+\mathrm{n} \log \mathrm{C}$

$\Theta$ is the degree of surface coverage for different concentrations of the extract in acidic media using the equations:

$\Theta=\mathrm{i}_{\operatorname{corr}(\Theta=0)}-\mathrm{i}_{\operatorname{corr} \Theta} \quad / \mathrm{i}_{\operatorname{corr}(\Theta=0)}-\mathrm{i}_{\operatorname{corr}(\Theta=1)}$

$\Theta=\mathrm{C}_{\mathrm{dl}(\Theta=0)}-\mathrm{C}_{\mathrm{dl} \Theta} / \mathrm{C}_{\mathrm{dl}(\Theta=0)}-\mathrm{C}_{\mathrm{dl}(\Theta=1)}$

$\mathrm{C}$ is the Aloe extract concentration in the bulk of the solution and $\mathrm{K}$ is the binding constant (equilibrium constant) for the adsorption process in which is evaluated from the intercepts of the plots and related to the standard free energy of adsorption, $\Delta \mathbf{G}_{\text {ads. }}^{\circ}$ as in the relation (23).

$\mathrm{K}=1 / 55.5$ exp. $\left(-\Delta \mathrm{G}_{\text {ads. }}^{\circ} / R \mathrm{~T}\right.$

The calculated values of $\mathrm{K}$ and $\Delta \mathrm{G}_{\text {ads. }}^{\circ}$ were found to be 1.06 and $-10.26 \mathrm{k} . J \cdot \mathrm{mol}^{-1}$ from polarization and the values 1.16 and $-10.50 \mathrm{k} . J$. mo..$^{-1}$ from impedance measurements, respectively, this is in agreement with that obtained in previous studies (E. Oquzic, 2007)(E. El- Etre, 2003).

The value of $\mathrm{K}$ is relatively small indicating that low interaction between the adsorbed molecules and the metal surface is found and the extract molecules are physically adsorbed on the Aluminium surface through adsorption of oxygen atom with lone pair of electron on Aloe molecules. The values of $\Delta \mathbf{G}_{\text {ads. }}$ also are large and acquire negative sign suggesting that the adsorption occurs spontaneously.

The inhibition of Aluminium corrosion by Aloe extract can be explained on the basis that the inhibition process of Aloe molecules found through the simple blocked of active area on Aluminium surface, on another side the inhibitor decreases the surface area for anodic dissolution and hydrogen evolution without affect the corrosion mechanism. The reaction between $\mathrm{HCl}$ and Aluminium metal which covered by Aloe molecules probably occurred by diffusion of hydrogen ions and chloride ions through the pours passive layer (metal - oxide -

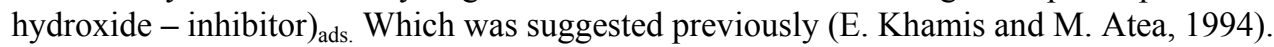

-Microstructure Study of Aluminium Surface by SEM at $30^{\circ} \mathrm{C}$ :

Scanning electron microscopy (SEM) was employed to study the surface morphology of Aluminium surface. The sample was studied after etching and $\backslash$ or 90 minutes immersion in the test solution, in both cases after mechanical polishing. Figure (11(a)) reveals the microstructure of polished Aluminium before placing it in the test solution. The scan shows that a solid and homogeneous surface is found.

Figure (11 (b)) illustrates the effect of $0.5 \mathrm{M} \mathrm{HCl}$ on Aluminium sample after 90 minutes immersion at $30^{\circ} \mathrm{C}$, it appears that the presence of general corrosion and pitting corrosion (a large number of vacuoles with different sizes).

Figure (11 (c)) exhibit the effect of $4 \% \mathrm{v} / \mathrm{v}$ of Aloe extract in $0.5 \mathrm{M} \mathrm{HCl}$, it obvious that the presence of thin porous and protection layer on Aluminium surface contain of numerous pits less than that appears in case of $\mathrm{HCl}$ acid alone, the pits are deep and contain a local cell and pitting corrosion which increase the corrosion rate (acceleration), Inh $\%=-12.90 \%$.

On comparing figure (11 (d)) which illustrates the effect of $48 \% \mathrm{v} / \mathrm{v}$ of Aloe extract in $0.5 \mathrm{M} \mathrm{HCl}$ at $30^{\circ} \mathrm{C}$ on Aluminium sample, it appears that the disappearance of vacuoles (pits) and the formation of an adsorbed film on Aluminium surface due to adsorption of Aloe extract components lead to high corrosion inhibition at this concentration. This confirms with the previous results obtained from electrochemical studies.

\subsection{Corrosion Inhibition of Aluminium in $0.5 \mathrm{M} \mathrm{HCl}$ at Different Concentrations of the Aloe Plant and Constant Concentration of Iodide Ions.}

The corrosion of Aluminium in $0.5 \mathrm{M} \mathrm{HCl}$ solutions containing different concentrations of Aloe extract and 0.01 $\mathrm{M}$ of iodide ions was studied electrochemically using polarization and impedance methods. 
Table (5) gives the values of corrosion potential $\left(\mathrm{E}_{\text {corr. }}\right)$, corrosion current $\left(\mathrm{I}_{\text {corr }) .}\right.$, corrosion resistance $\left(\mathrm{R}_{\text {corr. }}\right)$, charge transfer resistance $\left(\mathrm{R}_{\mathrm{ct}}\right)$, double layer capacitance $\left(\mathrm{C}_{\mathrm{dl}}\right)$ and inhibition efficiency (Inh.\%) obtained from the polarization and impedance plots. It clears those values of $\mathrm{E}_{\text {corr. }}$ remain constant with increase Aloe concentration in presence of $0.01 \mathrm{M}$ of NaI, where $\mathrm{I}_{\text {corr. }}$ and $\mathrm{R}_{\text {corr }}$.were decrease. The inhibition efficiency is also was found to increase with increasing concentration of Aloe extract. The values of $\mathrm{R}_{\mathrm{ct}}$ increase, while the values of $\mathrm{C}_{\mathrm{dl}}$ decrease, this explained on the basis that addition of iodide ions enhance the adsorption of Aloe molecules on Aluminium surface, by synergistic effect between I' ions and Aloe compounds (S. Syed Azim, S. Muralidharan and S. V. Iyer, 1995)( S. S. Abd El- Rahim, M. Sh. Shalaby and S. M. Abd El- Haleem, 1985)( S. Syed Azim, S. Muralidharan, S. V. Iyer, B. Muralidharan and T. Vasudevan, 1998).

The synergism parameter $\left(S_{\Theta}\right)$ was calculated using the relationship given by Aramaki and Hackermann (K. Aramaki and N. Hackerman, 1969):

$S_{\Theta}=\left(1-\Theta_{1+2}\right) /\left(1-\Theta^{\prime}{ }_{1+2}\right)$

where: $\Theta_{1+2}=\left(\Theta_{1}+\Theta_{2}\right)-\left(\Theta_{1} \Theta_{2}\right)$,

$\Theta_{1}=$ surface coverage by anion,

$\Theta_{2}=$ surface coverage by cation and,

$\Theta_{1+2}^{\prime}=$ measured surface coverage by both anion and cation.

These values are given in Table (6), which calculated for various concentrations of Aloe extract in presence of $0.01 \mathrm{M}$ of I' ions. Figure $(12(\mathrm{a} \& \mathrm{~b}))$ shows the plot of synergism parameter $\left(\boldsymbol{S}_{\theta}\right)$ against concentration of Aloe extract from polarization and impedance methods, respectively. The $S_{\Theta}$ values given in Table (6) are more than unity and this indicate that the enhanced inhibition efficiency caused by the addition of iodide ions to Aloe extract is only to a synergistic effect between $\mathrm{I}^{-}$ions and Aloe molecules (K. Aramaki, M. Hagiwara and H. Nishihawa, 1987)(G. K. Gomma, 1998)( M. A. Quraishi and J. Rawat, 2002), this can be attributed to cooperative adsorption between $\mathrm{I}^{-}$ions and Aloe cations. This can explained as: the attraction between $\mathrm{I}^{-}$ions and Aloe molecules lead to formation of ionic complex ExI' adsorbed on Aluminium surface by columbic attraction which lead to decrease the rate of corrosion by stabilisation of adsorbed anions and increase the covered area and increase the inhibition efficiency (A. Mohamed, T. Rakha, M. Moussa, 1990)( G. K. Gomma, 1998)( N. S. Rawat and G. Udayabhanu, 1987). The following reaction can be suggested as:

$\mathrm{Ex}=\mathrm{I}^{-} \leftrightarrow \mathrm{ExI}^{-}$

The complex ExI ${ }^{-}$adsorb on the Aluminium surface and cause the corrosion inhibition of Aluminium in $\mathrm{HCl}$.

Figure(13) shows the variation of inhibition efficiency with the concentration of Aloe extract in $0.5 \mathrm{M} \mathrm{HCl}$ containing $0.01 \mathrm{M} \mathrm{NaI}$ obtained from polarization and impedance measurements at $30^{\circ} \mathrm{C}$. The presence of $\mathrm{I}^{-}$ions enhanced the protection efficiency of Aloe extract especially at low concentrations

\subsection{Corrosion Inhibition of Aluminium in $0.5 \mathrm{M} \mathrm{HCl}$ at Fixed Concentration of Aloe Extract and Different Concentrations of Iodide Ions.}

The inhibition efficiency of $48 \% \mathrm{v} / \mathrm{v}$ of $\boldsymbol{A l o e}$ extract for Aluminium in $0.5 \mathrm{M} \mathrm{HCl}$ was determined for various concentrations $\left(1.0 \times 10^{-4}-5.0 \times 10^{-2}\right) \mathrm{M}$ of I- ions (Figs.(14,15)). It can be seen from these figures and Table (7) that Inh.\% was increased by adding $\mathrm{I}^{-}$ions until reach to $2.5 \times 10^{-2} \mathrm{M}$ then a decrease in the inhibition efficiency with increasing concentration of $\mathrm{I}^{-}$ions is occurred.

The increase of Inh.\% with increasing the concentration of NaI may explained as to be due to a joint adsorption (co- adsorption) of I' ions with inhibitor molecule. Adsorption of Aloe extracts molecules at Aluminium / solution interface occurred through physical adsorption via the oxygen atom with its positive charge and chemisorptions through the electron orbital of the benzene rings. It is known that $\mathrm{I}^{-}$ions have strong interaction with Aluminium surface owing to chemisorptions, but it gives an acceleration in absence of Aloe extract as inhibitor.

When the anion and Aloe extract coexist in solution, in terms of electrostatic attraction of these species, the ionic complex ExI $I^{-}$will formed between Aloe cations and $\mathrm{I}^{-}$ions and adsorb on Aluminium surface which lead to increase the coverage and enhance the inhibition (Y. Feng, K. S. Siow, W. K. Teo and A. K. Hsieh, 1999).

Figure (16) and Table (8) show the relation between $\mathrm{S}_{\Theta}$ and $\mathrm{C}$ of $\mathrm{I}^{-}$ions, which appears that $\mathrm{S}_{\Theta}>1$ indicate that the presence of synergistic effect between $\mathrm{I}^{-}$ions and Aloe molecules as a result of co- adsorption. 
The addition of I- leads to stabilisation of Aloe extract adsorption on Aluminium surface by the interaction between Aloe molecules and iodide ions. The formation of the ionic complex which adsorbed through iodide ions on the surface of Aluminium(Y. Feng, K. S. Siow, W. K. Teo and A. K. Hsieh, 1999).

From these results, iodide ions in NaI are suggested to have synergistic effect with Aloe extract only at low concentrations because it was prevent the acceleration and enhance the inhibition of Aluminium corrosion.

The decrease of Inh.\% indicates that desertion takes place at Al / acid solution interface. Assuming that the adsorption of the inhibitor molecules and the anions is ionic in nature and of the overlap type, then the addition of more anions might give rise to a weak combination of anions and Aloe cations, and as a result make the cations desorbed. Desertion of the cations will then result in their replacement with water molecules.

From previous results, it is known that $\mathrm{NaI}$ could be considered as one of the effective anions for synergistic action within the Aloe plant inhibitor.

\section{Conclusion:}

The effect of acid concentration and the effect of addition the aqueous extract of Aloe plant on the corrosion of Aluminium has been studied. The following conclusions may be drawn:

1) The chemical results showed that the corrosion rate of Aluminium sample is increase with increasing acid concentrations (0.25-1.5) $\mathrm{M}$.

2) The polarization measurements also showed that, the increase of $\mathrm{HCl}$ concentration leads to displacement of the anodic and cathodic curves to high current densities $\left(\mathrm{I}_{\text {corr. }}\right)$, also increase the corrosion rate will be found.

3) The electrochemical impedance measurements showed that the corrosion of Aluminium sample is mainly controlled by charge transfer process.

4) The aqueous extract of Aloe plant acts as good inhibitor for the corrosion of Aluminium metal in $\mathrm{HCl}$ solution.

5) Electrochemical polarization results indicates that the Aloe aqueous extract act as mixed type inhibitor and impedance results showed that the corrosion of Aluminium is mainly controlled by a charge transfer process and the presence of Aloe extract in acid solution does not alter the mechanism of Aluminium dissolution.

6) The adsorption of Aloe extract molecules on Aluminium metal surface follows Freundlish adsorption isotherm, the values of $\mathrm{K}_{\text {ads. }}$ and $\Delta \mathrm{G}_{\text {ads. }}$ indicate physical adsorption of Aloe molecules on Aluminium surface.

7) The addition of $0.01 \mathrm{M} \mathrm{NaI}$ to Aluminium sample in $\mathrm{HCl}$ in presence of different concentrations(4-60)\%v/v of Aloe extract enhances the inhibition efficiency of Aloe plant, and the addition of different concentrations $\left(1.0 \times 10^{-4}-5.0 \times 10^{-2}\right) \mathrm{M}$ of NaI in the presence of $48 \% \mathrm{v} / \mathrm{v}$ of Aloe extract leads to increase the Inh.\% by $\mathrm{I}^{-}$ions reach to $2.5 \times 10^{-2} \mathrm{M}$ then a decrease in the Inh.\% with

\section{References} increasing concentration will occurred.

A. A. Mazhar, S. T. Arab and E. A. Noor, J. App. Electrochem., 3,113(2001).

A. Bouyanzer and B. Hammouti, Pihment \& Resin Technology, 33(5), 287(2004).

A. El-Etre, M. Abdullah and Z. El-Tantawy, Corros. Sci., 47, 385(2005).

A. Fouda, H. El-Nadar and M. Moussa, Acta Chemica Hungarica, 124(4), 581(1987).

A. M. Al- Mayouf, Corros. Priv. Cont.,6, 70(1996).

A. M. Beccaria and G. Poggi, Corrosion, 42(8), 470(1986).

A. Mohamed, T. Rakha, M. Moussa, Bull. Soc. Chem. Fr., 127, 375(1990).

A. Y. El-Eter, Corros. Sci., 45, 2485(2003).

A.M.Mohamed, A.Al-Nadjm and A.A,Fouda, 2061(1998).

B. Berge, K. Grijotheim, C. Kronhn, R. Ncumann and K. Torkiep, Light Metals, (edited by S R Leavitt) Proceeding of $\mathbf{1 0 5}^{\text {th }}$ annual meeting, 23(1976).

B. K. Gary, R. A. V. Raff and R. V. Subramanian, NTISAD Rep., 1977 from Gov. Rep. Announce Index (U. S.) 158, 7711(1977); C. A; 87, 5458614; F. S. Tech., R. Mahalingam, R. V. Subramanian and R. A. V. Raff, J. Electrochem. Soc., 142, 995(1977) 
B. R. Baker and J. D. Balser, Aluminum, 52, 197(1976).

C. Brett, I. Gomes and J. Marhins, Corros. Sci., 36(6),915(1994).

C. N. A. Brett, J. Appl. Electrochem., 20, 1000(1990).

E. E. Oquzic, G. N.Onuoha and E. N. Ejibe, Pigment \& Resin Technology, 36 (1), 44(2007).

E. E. Oquzic, Mater. Chem. Phys., 99(2-3), 441(2006).

E. El- Etre, Corros. Sci., 45, 2485(2003).

E. Khamis and M. Atea, Corros. Sci., 50(2), 106(1994).

E. Marboe and S. Bentur, Sicliates Ind., 26, 389(1961).

E. McCaffety, Corros. Sci., 45, 1421(2003).

E. Oquzic, Corros. Sci. 49, 1527(2007).

F. Bentiss, M. Lagrenee, M.Traisnel, B. Mernani and H. Elattari, J. App. Electrochem., 29(9), 1073(1999).

F. Mansfeld, M. W. Kending and S. Tasi, Corrosion, 37, 301(1980).

F. Mansfeld, M. W. Kending and S. Tasi, Corrosion, 38, 750(1982).

F. Mylius and S. Niethem, J. Amer. Chem. Soc., 79, 1966(1957).

F. P. Ford, G. T. Burstein and T. P. Hoar, J. Electrochem. Soc., 127, 1325(1980).

F. Zucchi, I. H. Omar, Surf. Tech., 24, 391(1985).

G. B. Hunt and A. K. Holiday. Org. Chem. London, United Kingdom: Buterworth, 229(1980).

G. Banerjee and S. N. Malhotra, Corrosion, 48(1), 10(1992).

G. K. Gomma, Mater. Chem. \& Phys., 55, 243(1998).

G. Warnglen " An Intrduction to Corrosion and Protection of Metals ", Champan and Hall., New York, London(1985).

J. H. de Boer, in:H. Mark, E. J. W. Verwey(Eds.), Advances in Colloid Science, Vol.III, Interscience Publishers, New York,(1950).

K. Aramaki and N. Hackerman, J. Electrochem. Soc., 116, 568(1969).

K. Aramaki, M. Hagiwara and H. Nishihawa, Corros. Sci., 27, 487(1987).

K. Srivastava and P. Srivastava,Br. Corrs. J., 16(4), 221(1981).

M. A. Quraishi and J. Rawat, Mater. Chem. \& Phys., 73, 118(2002).

M. Abdallah, Bull. Electrochem., 16(6), 258(2000).

M. Abdallah, Portugalia Electrochem. Acta, 22, 161(2004).

M. Abdlallah, Corros. Sci., 46, 1981(2004).

M. Hurovic, R. Babic, Z. Grubac and S. Brinic, J. Electrochem., 24, 772(1994).

M. Kliskic, J. Radosevic, S. Gudic and V. Katalinik, J. Appl. Electrochem., 30, 823(2000).

M. Kliskic, J.Radosevic, S. Gudic and V. Katalinik, J. Appl. Electrochem., 30, 823(2000).

M. M. Saleh, Mater. Chem. \& Phys., 98, 83(2006).

M. Quraishi, I. Farooqi and P. Saini, Corrosion, 55(5), 493(1999).

N. S. Rawat and G. Udayabhanu, Proceeding of the $\mathbf{1 0}^{\text {th }}$ International Congress on Metallic Corrosion Organized by CECRI at Madras, 3(13), 2963(1987).

P. S. Khosla, J. B. Singh and R. K. Srivastava, Indian J. Pharma., 32, 372(2000).

R. Ambat and E. S. Dwarakadasa, Br. Corrs. J., 28(2), 142(1993).

S. Rengamanmi, S. Muralidharan, M. Anbu Kulandainathan and S. U. Iyer, J. App. Electrochem., 24, 355(1994).

S. S. Abd El- Rahim, M. Sh. Shalaby and S. M. Abd El- Haleem, Surf. Technol., 24, 241(1985).

S. Syed Azim, S. Muralidharan and S. V. Iyer, J. Appl. Electrochem., 25, 495(1995).

S. Syed Azim, S. Muralidharan, S. V. Iyer, B. Muralidharan and T. Vasudevan, Br. Corros. J., 33(4), 297(1998). 
S. T. Arab and A. M. Al-Tukustani, International J. Chem., 12(4), 249(2002).

T. H. Nguyen and R. T. Foley, J. Electrochem. Soc., 129, 32(1982).

T. Tsura, S. Haruyama and B. Gijutsu, J. Jpn. Soc. Corros. Eng., 27, 570(1978).

T. U. Chavanin, Corrosion, 47(6), 472(1991).

T. Blitzke, A. Porzel, M. Masaoud and J. Schmidt, Phytochemistry, 55, 979(2000).

V. Branzoi, F. Golgovici and F. Branzoi, Mrter. Chem. \& Phys., 78, 122(2002).

Y. Feng, K. S. Siow, W. K. Teo and A. K. Hsieh, Corros. Sci., 41, 829(1999).

Table 1. Chemical composition of Aluminum specimen.

\begin{tabular}{|r|r|r|r|r|r|r|r|}
\hline Element & $\boldsymbol{M n}$ & $\boldsymbol{N i}$ & $\boldsymbol{F e}$ & $\boldsymbol{P b}$ & $\boldsymbol{S i}$ & $\boldsymbol{Z n}$ & $\boldsymbol{C r}$ \\
\hline$\%$ & 0.009 & 0.043 & 0.765 & 0.014 & 2.242 & 1.621 & 0.009 \\
\hline
\end{tabular}

Table 2. Corrosion rates ( $\mathrm{R}$ and $\mathrm{R}^{\prime}$ ) for Aluminum sample at different concentrations of $\mathrm{HCl}$ at $30^{\circ} \mathrm{C}$.

\begin{tabular}{|c|c|c|c|c|c|c|}
\hline$C(M)$ & 0.25 & 0.5 & 0.75 & 1.0 & 1.25 & 1.5 \\
\hline $\begin{array}{c}\boldsymbol{R} \\
\text { ml. } \text { min. }^{-1} \\
\text { min }^{-2}\end{array}$ & $0.1623 \times 10^{-2}$ & $7.917 \times 10^{-2}$ & $13.21 \times 10^{-2}$ & $22.73 \times 10^{-2}$ & $29.25 \times 10^{-2}$ & $65.80 \times 10^{-2}$ \\
\hline$\stackrel{R^{\prime}}{\text { g. } \mathrm{cm}^{-2} \min ^{-1}}$ & $0.1300 \times 10^{-5}$ & $2.580 \times 10^{-5}$ & $9.011 \times 10^{-5}$ & $14.63 \times 10^{-5}$ & $15.20 \times 10^{-5}$ & $43.00 \times 10^{-5}$ \\
\hline
\end{tabular}

Table 3. Electrochemical parameters for corrosion of Aluminium in different concentrations of $\mathrm{HCl}$ at $30^{\circ} \mathrm{C}$.

\begin{tabular}{|c|c|c|c|c|c|c|c|c|}
\hline \multirow{2}{*}{$\begin{array}{c}\text { Conc. } \\
\text { (M) }\end{array}$} & \multicolumn{5}{|c|}{ Polarization } & \multicolumn{3}{|c|}{ Impedance } \\
\hline & $\begin{array}{l}-\mathrm{E}_{\mathrm{carr}} \\
(\mathrm{mV})\end{array}$ & $\begin{array}{c}\mathrm{b}_{\mathrm{a}} \\
\left(m V \operatorname{dec}^{*}\right)\end{array}$ & $\begin{array}{c}\mathrm{b}_{\mathrm{c}^{*}} \\
\left(m V \operatorname{dec} c^{\prime}\right)\end{array}$ & $\begin{array}{c}\mathrm{C}_{\mathrm{dl}} \\
(\mu F)\end{array}$ & $\begin{array}{c}\mathrm{R}_{\mathrm{e}} \\
\left(\Omega \mathrm{cm}^{2}\right)\end{array}$ & $\begin{array}{c}\mathrm{R}_{\text {sal }} \\
\left(\Omega \mathrm{cm}^{2}\right)\end{array}$ & $\begin{array}{c}\mathrm{R}_{\mathrm{s}:} \\
\left(\Omega \mathrm{cm}^{2}\right)\end{array}$ & $\begin{array}{l}\mathrm{C}_{\mathrm{dl}} \\
(\mu F)\end{array}$ \\
\hline 0.25 & 693.805 & 34.25 & 207.88 & 2.181 & 23.751 & 1.347 & 79.85 & 78.510 \\
\hline 0.50 & 726.573 & 44.55 & 131.22 & 7.282 & 79.300 & 0.584 & 42.52 & 102.50 \\
\hline 0.75 & 754.973 & 71.85 & 139.42 & 19.48 & 212.17 & 1.206 & 8.891 & 161.90 \\
\hline 1.00 & 759.342 & 87.17 & 174.03 & 23.06 & 251.12 & 2.755 & 2.599 & 237.70 \\
\hline 1.25 & 766.990 & 106.60 & 103.75 & 33.46 & 364.40 & 0.864 & 0.420 & 440.75 \\
\hline 1.50 & 774.635 & 138.02 & 132.15 & 39.36 & 428.58 & 0.890 & 0.156 & 472.50 \\
\hline
\end{tabular}

Table 4. Electrochemical parameters and inhibition percentages of Aluminium corrosion in $0.5 \mathrm{M} \mathrm{HCl}$ in presence of different concentrations of Aloe extract at $30^{\circ} \mathrm{C}$.

\begin{tabular}{|c|c|c|c|c|c|c|c|c|c|c|}
\hline \multirow[b]{2}{*}{$\begin{array}{c}\text { Conc. } \\
V / V\end{array}$} & \multicolumn{6}{|c|}{ Polarization } & \multicolumn{4}{|c|}{ Impedance } \\
\hline & $\begin{array}{l}-\mathrm{E}_{\mathrm{sarr}} \\
(\mathrm{mV})\end{array}$ & $\begin{array}{c}\mathrm{b}_{\mathrm{a}} \\
\left(V \operatorname{dec}^{\cdot l}\right)\end{array}$ & $\begin{array}{c}\mathrm{b}_{\mathrm{c}^{*}} \\
\left(V \mathrm{dec}^{*}\right)\end{array}$ & $\begin{array}{c}\mathrm{I}_{\mathrm{carr}} \\
\left(\mathrm{mA} \cdot \mathrm{cm}^{2}\right)\end{array}$ & $\begin{array}{c}\mathrm{R}_{\text {carr }} \\
(m m \text { day }\end{array}$ & $\operatorname{lnh} \%$ & $\begin{array}{c}\mathrm{R}_{\mathrm{sal}} \\
\left(\Omega \mathrm{cm}^{2}\right)\end{array}$ & $\begin{array}{c}\mathrm{R}_{\mathrm{ct}} \\
\left(\Omega \mathrm{cm}^{2}\right)\end{array}$ & $\begin{array}{c}\mathrm{C}_{\mathrm{dl}} \\
(\mu F)\end{array}$ & $\begin{array}{c}\operatorname{Inh} . \\
\%\end{array}$ \\
\hline 0.0 & $\begin{array}{c}762.5 \\
7\end{array}$ & 44.55 & 131.22 & 7.28 & 79.30 & - & 0.584 & 42.52 & 102.5 & - \\
\hline 4 & $\begin{array}{c}737.3 \\
6\end{array}$ & 85.82 & 15.05 & 7.36 & 80.11 & -1.07 & 2.331 & 59.25 & $\begin{array}{c}122.0 \\
0\end{array}$ & 15.00 \\
\hline 8 & $\begin{array}{c}740.2 \\
2\end{array}$ & 78.30 & 15.02 & 5.99 & 65.18 & 17.74 & 1.322 & 68.01 & $\begin{array}{c}113.6 \\
0\end{array}$ & 25.00 \\
\hline 20 & $\begin{array}{c}735.4 \\
6\end{array}$ & 104.57 & 19.45 & 3.08 & 33.59 & 57.70 & 1.605 & 80.81 & 69.67 & 40.00 \\
\hline 40 & $\begin{array}{c}737.3 \\
6\end{array}$ & 63.28 & 25.38 & 2.73 & 29.75 & 62.51 & 2.268 & 99.77 & 63.82 & 50.00 \\
\hline 48 & $\begin{array}{c}728.8 \\
1\end{array}$ & 45.69 & 75.44 & 2.16 & 23.49 & 70.34 & 1.198 & 200.40 & 50.55 & 75.05 \\
\hline 60 & $\begin{array}{c}729.2 \\
7\end{array}$ & 71.37 & 63.25 & 1.26 & 13.75 & 82.69 & 1.052 & 359.50 & 21.19 & 88.42 \\
\hline
\end{tabular}


Table 5. Electrochemical parameters and inhibition percentages for the corrosion of Aluminium in presence of various concentrations of $\boldsymbol{A l o e}$ plant extract and in presence of $0.01 \mathrm{M} \mathrm{NaI}$ at $30^{\circ} \mathrm{C}$.

\begin{tabular}{|c|c|c|c|c|c|c|c|c|c|c|}
\hline \multirow[b]{2}{*}{$\begin{array}{c}\text { Conc } \\
\text { V/V }\end{array}$} & \multicolumn{6}{|c|}{ Polarization } & \multicolumn{4}{|c|}{ Impedance } \\
\hline & $\begin{array}{l}-\mathrm{E}_{\text {earr }} \\
(m V)\end{array}$ & $\left(m V^{b_{2}} d e c^{*}\right.$ & $\left(m V d_{c e}^{*}\right)$ & $\begin{array}{c}\mathrm{I}_{\mathrm{carr}} \\
(\mathrm{mA} \cdot \mathrm{cm} \\
\left.{ }_{2}\right)\end{array}$ & $\underset{\left(m m \text { day }^{* I}\right)}{\mathrm{R}_{\text {cart. }}}$ & $\operatorname{lnh} \%$ & $\begin{array}{c}\mathrm{R}_{\text {sol. }} \\
\left(\Omega \mathrm{cm}^{2}\right)\end{array}$ & $\begin{array}{c}\mathrm{R}_{\mathrm{ct}} \\
\left(\Omega \mathrm{cm}^{2}\right)\end{array}$ & $\begin{array}{c}\mathrm{C}_{\mathrm{d} 1} \\
(\mu F)\end{array}$ & $\begin{array}{c}\operatorname{Inh} . \\
\%\end{array}$ \\
\hline 0.0 & $\begin{array}{c}726.5 \\
7\end{array}$ & 44.55 & 131.22 & 7.28 & 79.30 & $\ldots . .$. & 0.584 & 42.52 & 102.5 & ........ \\
\hline 4 & $\begin{array}{c}725.8 \\
0\end{array}$ & 33.01 & 110.71 & 8.22 & 89.51 & -12.9 & 0.696 & 47.78 & 99.50 & 12.5 \\
\hline 8 & $\begin{array}{c}737.0 \\
3 \\
\end{array}$ & 97.22 & 14.60 & 6.01 & 65.47 & 17.47 & 1.514 & 50.90 & 96.80 & 18.33 \\
\hline 20 & $\begin{array}{c}731.4 \\
9\end{array}$ & 33.98 & 119.81 & 3.27 & 35.62 & 55.10 & 2.665 & 56.71 & 84.50 & 26.67 \\
\hline 40 & $\begin{array}{c}726.0 \\
7\end{array}$ & 72.32 & 24.75 & 3.17 & 34.56 & 56.50 & 0.737 & 62.52 & 59.20 & 33.38 \\
\hline 48 & $\begin{array}{c}732.0 \\
5 \\
\end{array}$ & 71.89 & 15.14 & 2.68 & 29.16 & 63.20 & 0.525 & 87.23 & 57.80 & 52.23 \\
\hline 60 & $\begin{array}{c}731.1 \\
9\end{array}$ & 79.64 & 15.17 & 1.45 & 15.79 & 80.09 & 3.592 & 181.1 & 37.94 & 77.0 \\
\hline
\end{tabular}

Table 6. Synergism parameters for the corrosion of Aluminium in $0.5 \mathrm{M} \mathrm{HCl}$ in presence of Aloe plant extract and $0.01 \mathrm{M} \mathrm{NaI}$ at $30^{\circ} \mathrm{C}$.

\begin{tabular}{|c|c|c|}
\hline Conc. Of Iodide Ions & $\boldsymbol{S}_{\boldsymbol{\theta}}(\boldsymbol{P})$ & $\boldsymbol{S}_{\boldsymbol{\theta}}(\boldsymbol{I})$ \\
\hline $\mathbf{1 . 0} \times 10^{-4}$ & 1.81 & 4.25 \\
\hline $\mathbf{2 . 5} \times 10^{-3}$ & 1.75 & 3.55 \\
\hline $\mathbf{1 . 0} \times 10^{-2}$ & 2.31 & 3.47 \\
\hline $\mathbf{2 . 5} \times 10^{-2}$ & 1.68 & 3.24 \\
\hline $\mathbf{3 . 0} \times 10^{-2}$ & 1.45 & 2.73 \\
\hline $\mathbf{5 . 0} \times 10^{-2}$ & 1.10 & 1.71 \\
\hline
\end{tabular}

Table 7. Electrochemical parameters and inhibition percentages for the corrosion of Aluminium in $0.5 \mathrm{M} \mathrm{HCl}$ in presence of $48 \% \mathrm{v} / \mathrm{v}$ Aloe extract and different concentrations of $\mathrm{NaI}$ at $30^{\circ} \mathrm{C}$.

\begin{tabular}{|c|c|c|c|c|c|c|c|c|c|c|}
\hline \multirow[b]{2}{*}{$\begin{array}{c}\text { Conc. } \\
V / V\end{array}$} & \multicolumn{6}{|c|}{ Polarization } & \multicolumn{4}{|c|}{ Impedance } \\
\hline & $\begin{array}{l}-\mathrm{E}_{\mathrm{carr}} \\
(\mathrm{mV})\end{array}$ & $\begin{array}{c}\mathrm{b}_{2} \\
(V d e c \\
l_{j}\end{array}$ & $\begin{array}{c}\mathrm{b}_{\varepsilon^{*}} \\
\left(V \operatorname{dec}^{\cdot /}\right)\end{array}$ & $\left(m A_{2}, \mathrm{~cm}\right.$ & $\underset{\left.\text { (mm day }{ }^{\cdot I}\right)}{\mathrm{R}_{\text {sars }}}$ & $\operatorname{lnh} \%$ & $\begin{array}{c}\mathrm{R}_{\text {sol. }}, \\
\left(\Omega \mathrm{cm}^{2}\right)\end{array}$ & $\begin{array}{c}\mathrm{R}_{\mathrm{ct}} \\
\left(\Omega \mathrm{cm}^{2}\right)\end{array}$ & $\begin{array}{l}\mathrm{C}_{\mathrm{dl}} \\
(\mu F)\end{array}$ & $\operatorname{lnh} \%$ \\
\hline 48 & 732.05 & 71.89 & 15.14 & 2.68 & 29.16 & 63.20 & 0.525 & 87.23 & 57.80 & 52.23 \\
\hline $1.0 \times 1 \theta^{4}$ & 731.0 & 70.50 & 128.33 & 4.01 & 43.70 & 44.94 & 1.437 & 150.0 & 48.66 & 66.67 \\
\hline $2.5 \times 10^{3}$ & 726.08 & 67.17 & 141.87 & 3.16 & 34.40 & 56.61 & 0.822 & 164.1 & 58.39 & 69.53 \\
\hline $1.0 \times 10^{2}$ & 728.81 & 45.69 & 75.44 & 2.16 & 33.22 & 70.34 & 2.427 & 193.8 & 50.31 & 74.2 \\
\hline $2.5 \times 10^{2}$ & 747.22 & 111.04 & 30.97 & 1.96 & 30.93 & 73.08 & 3.792 & 304.0 & 30.59 & 83.55 \\
\hline $3.0 \times 10^{2}$ & 743.16 & 101.54 & 26.48 & 2.02 & 22.06 & 72.26 & 2.135 & 276.1 & 41.00 & 81.90 \\
\hline $5.0 \times 10^{2}$ & 731.77 & 92.19 & 32.05 & 2.11 & 22.96 & 71.02 & 1.467 & 198.9 & 48.14 & 74.90 \\
\hline
\end{tabular}


Table 8. Synergism parameters for the corrosion of Aluminium in $0.5 \mathrm{M} \mathrm{HCl}$ in presence of $48 \%$ of Aloe plant extract and different concentration of $\mathrm{NaI}$ at $30^{\circ} \mathrm{C}$.

\begin{tabular}{|c|c|c|}
\hline Conc. Of Aloe $V / V$ & $\boldsymbol{S}_{\boldsymbol{\theta}}(\boldsymbol{P})$ & $\boldsymbol{S}_{\boldsymbol{\theta}}(\boldsymbol{I})$ \\
\hline $\mathbf{4}$ & 2.08 & 1.76 \\
\hline $\boldsymbol{8}$ & 1.88 & 1.86 \\
\hline $\mathbf{2 0}$ & 1.98 & 2.09 \\
\hline 40 & 2.16 & 2.28 \\
\hline 48 & 2.31 & 3.28 \\
\hline 60 & 2.14 & 3.39 \\
\hline
\end{tabular}

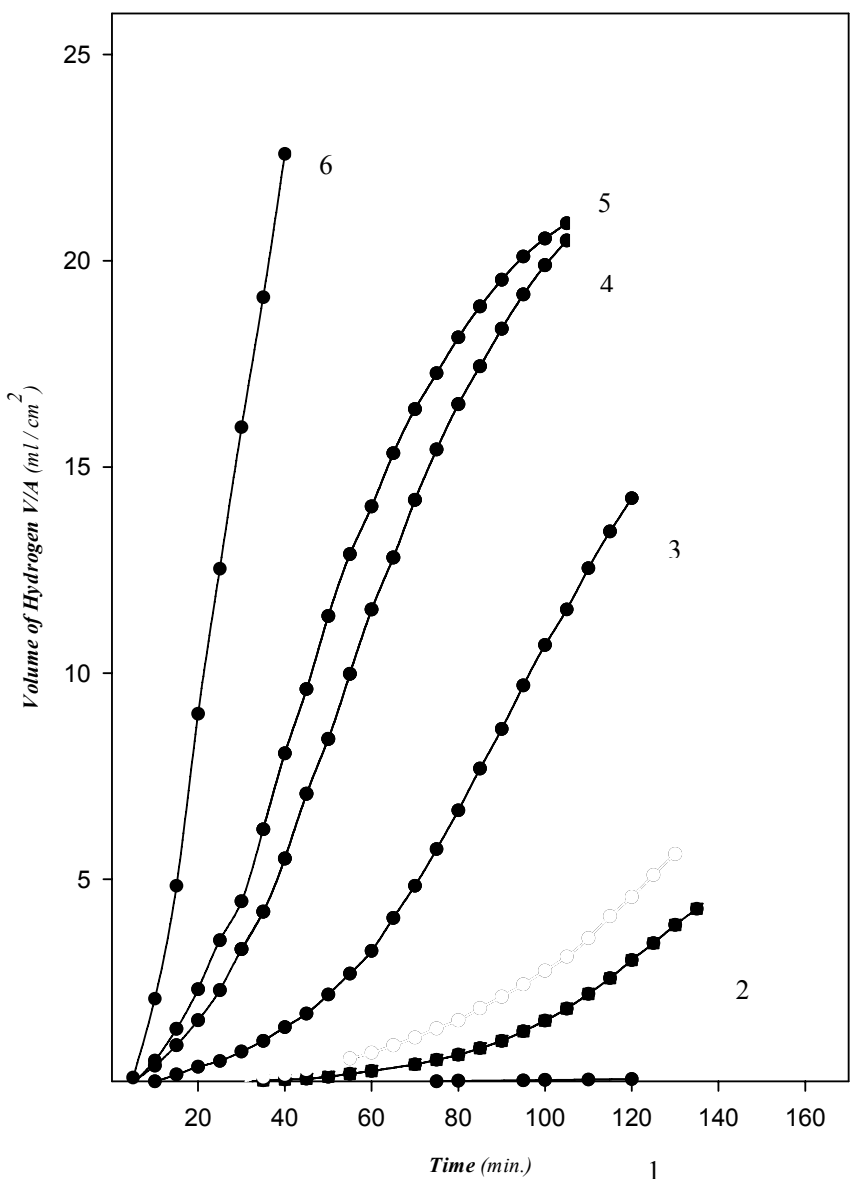
(1) $0.25 \mathrm{M}$ (2) $0.50 \mathrm{M} \mathrm{(3)} 0.75 \mathrm{M}$
(4) $1.00 \mathrm{M}$
(5) $1.25 \mathrm{M}$
(6) $1.5 \mathrm{M}$

Figure 1. Volume of hydrogen / time curves of $\mathrm{Al}$ in different concentrations of $\mathrm{HCl}$ at $30^{\circ} \mathrm{C}$. 

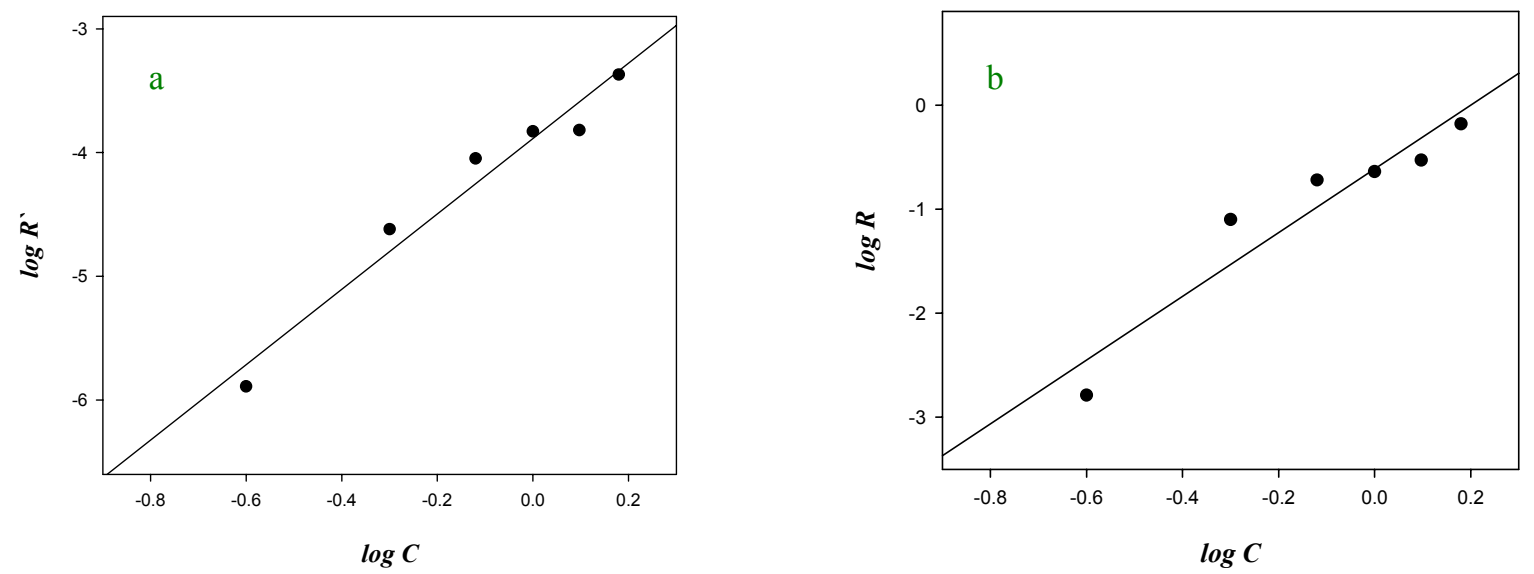

Figure 2. Vriation of (a) $\log \mathrm{R}^{\prime}(\mathrm{b}) \log \mathrm{R}$ of $\mathrm{Al}$ sample with the concentration of $\mathrm{HCl}$ at $30^{\circ} \mathrm{C}$.

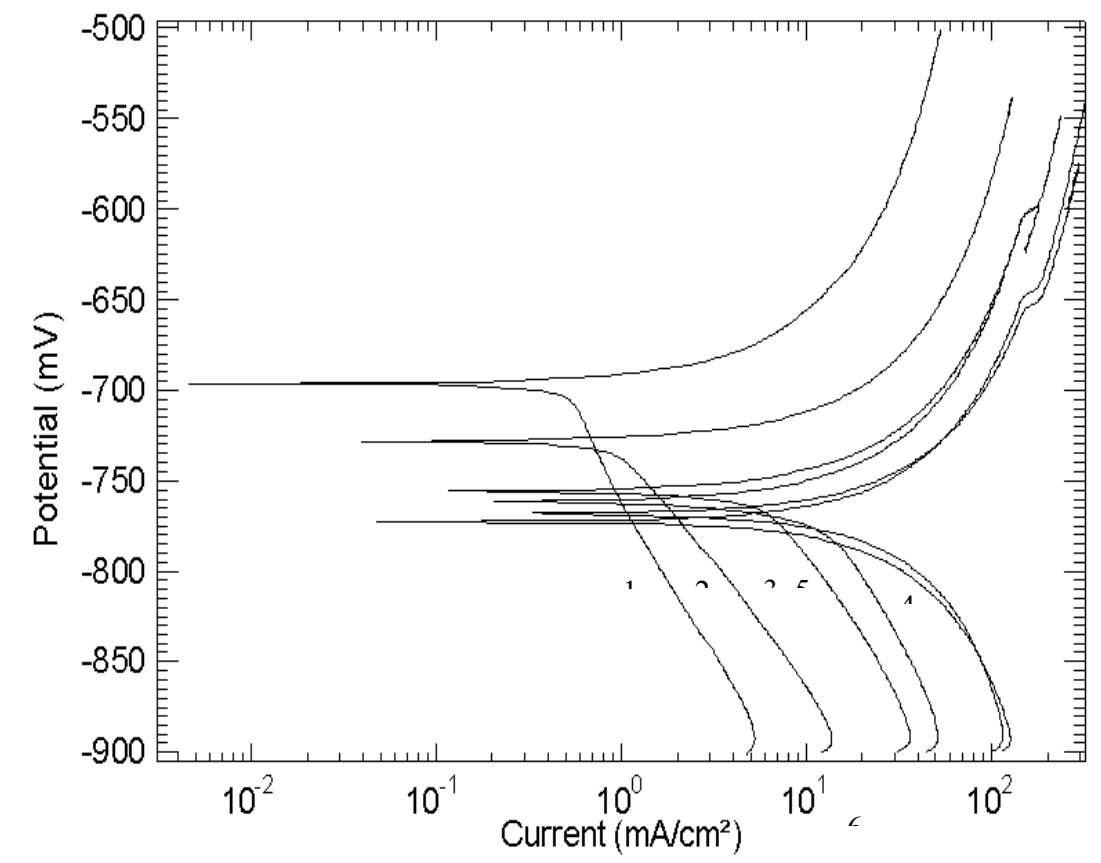

(1) $0.25 \mathrm{M} \mathrm{(2)} 0.50 \mathrm{M} \mathrm{(3)} 0.75 \mathrm{M}$ (4) $1.00 \mathrm{M}$ (5) $1.25 \mathrm{M}$ (6) $1.50 \mathrm{M}$

Figure 3. Polarization curves for $\mathrm{Al}$ sample corrosion in different concentrations of $\mathrm{HCl}$ solution at $30^{\circ} \mathrm{C}$ 

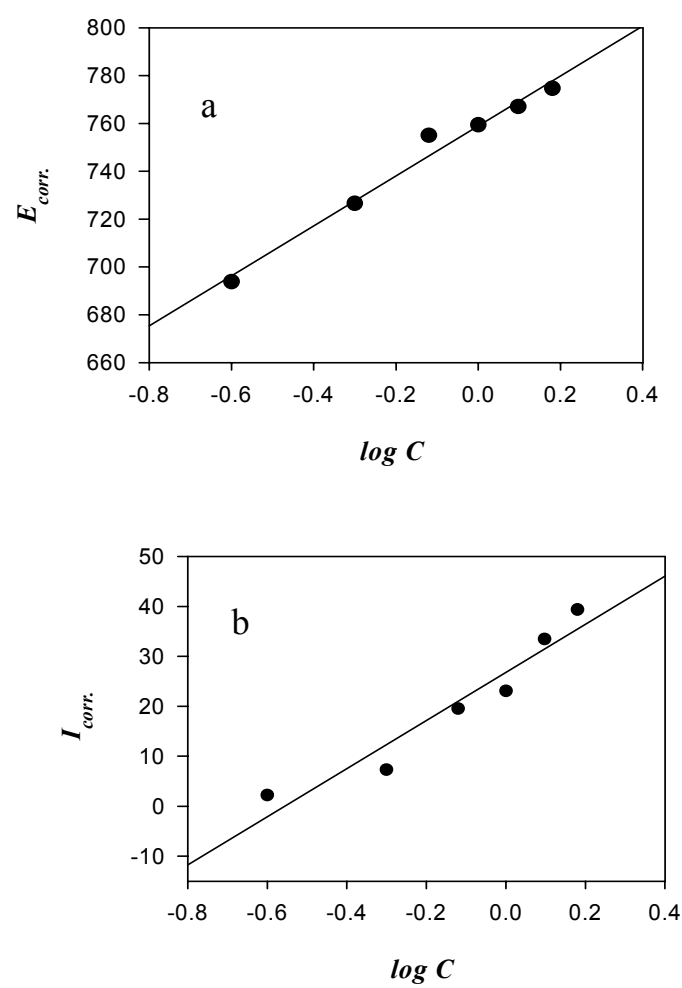

Figure 4. Vriation of (a) Ecorr. (b) Icorr. of Al sample with the concentration of $\mathrm{HCl}$ at $30^{\circ} \mathrm{C}$.
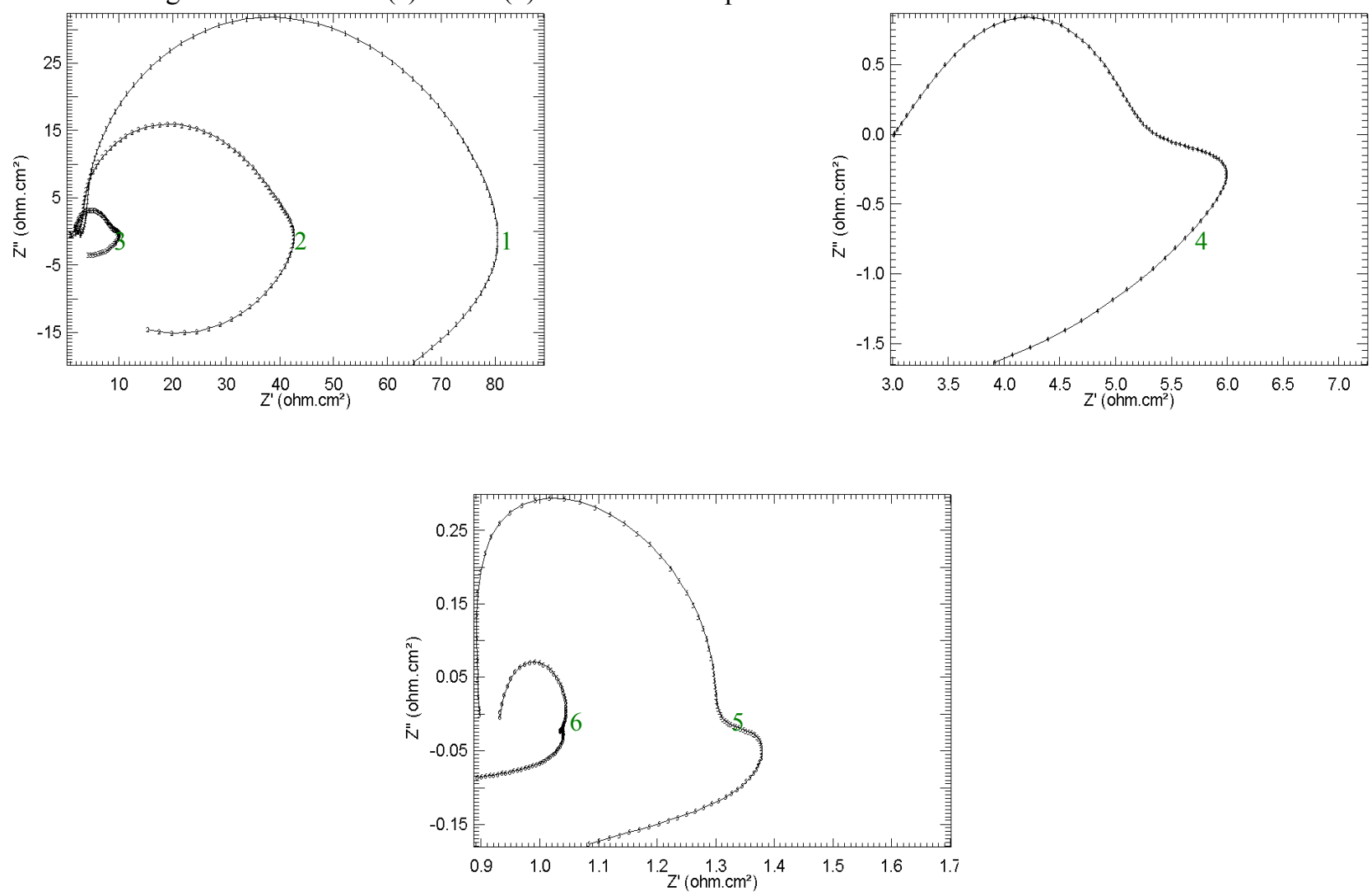

(1) $0.25 \mathrm{M}$ (2) $0.50 \mathrm{M}$ (3) $0.75 \mathrm{M}$ (4) $1.00 \mathrm{M}$ (5) $1.25 \mathrm{M}$ (6) $1.50 \mathrm{M}$

Figure 5. Nyquist plot for $\mathrm{Al}$ sample corrosion in differen concentrations of $\mathrm{HCl}$ solution at $30^{\circ} \mathrm{C}$. 


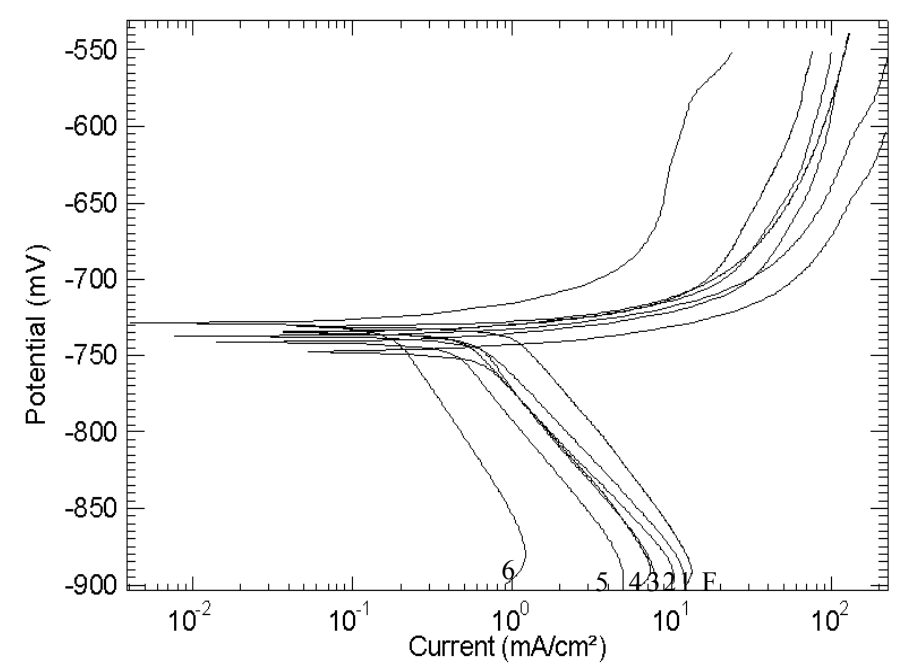

[(F) $0.00 \mathrm{M} \mathrm{(1)} 4.0$ (2) 8.0 (3) 20.0 (4) 40.0 (5) 48.0 (6) 60.0] V/V

Figure 6. Polarization curves for $\mathrm{Al}$ sample corrosion in different concentrations of $\boldsymbol{A l o e}$ extract at $30^{\circ} \mathrm{C}$.

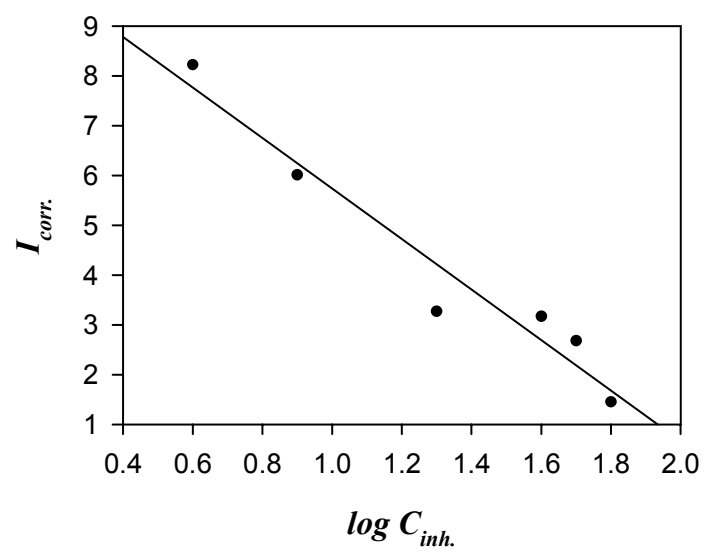

Figure 7. Vriation of $\mathrm{I}_{\text {corr. }}$ of Al sample with the concentrations of Aloe extract at $30^{\circ} \mathrm{C}$.

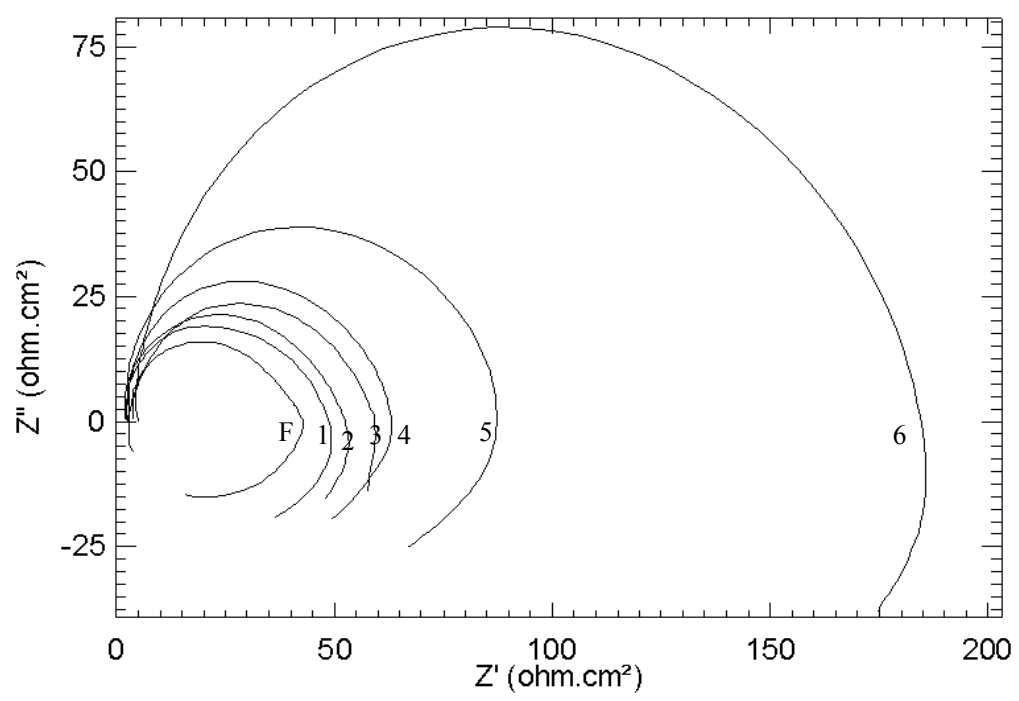

Figure 8. Nyquist plot for Al sample corrosion in differen concentrations of Aloe extract at $30^{\circ} \mathrm{C}$. 

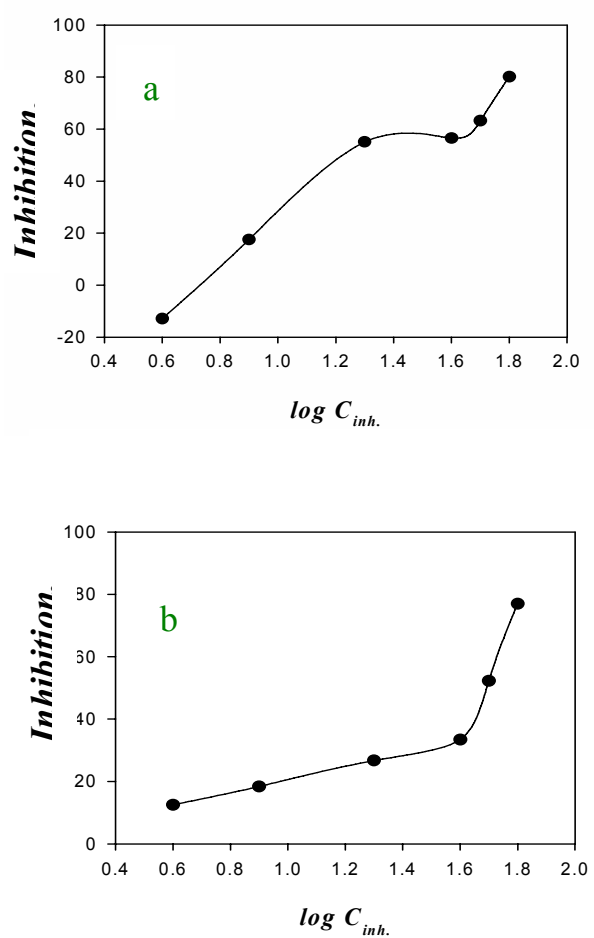

Figure 9. The relation between inhibition efficiency and the logarithm of concentration of Aloe extract for the corrosion of $\mathrm{Al}$ sample in $0.5 \mathrm{M} \mathrm{HCl}$ at $30^{\circ} \mathrm{C}$ from (a) polarization (b) impedance.
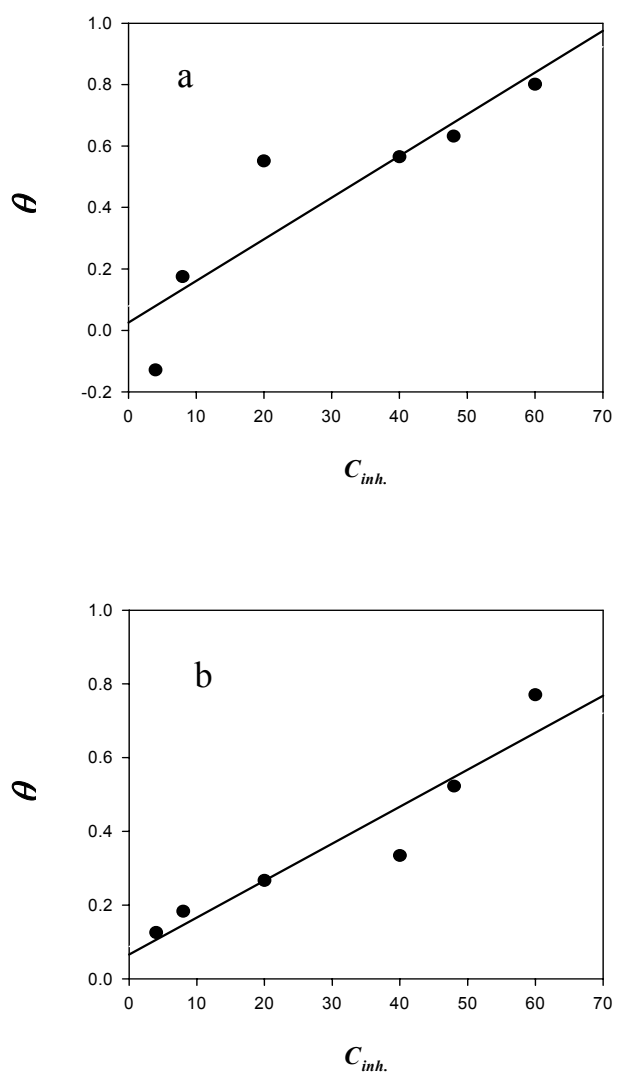

Figure 10. The relation between Cinh. and for the corrosion of $\mathrm{Al}$ sample in $0.5 \mathrm{M} \mathrm{HCl}$ in presence of different concentrations of Aloe extract in at $30^{\circ} \mathrm{C}$ from (a) polarization, (b) impedance . 

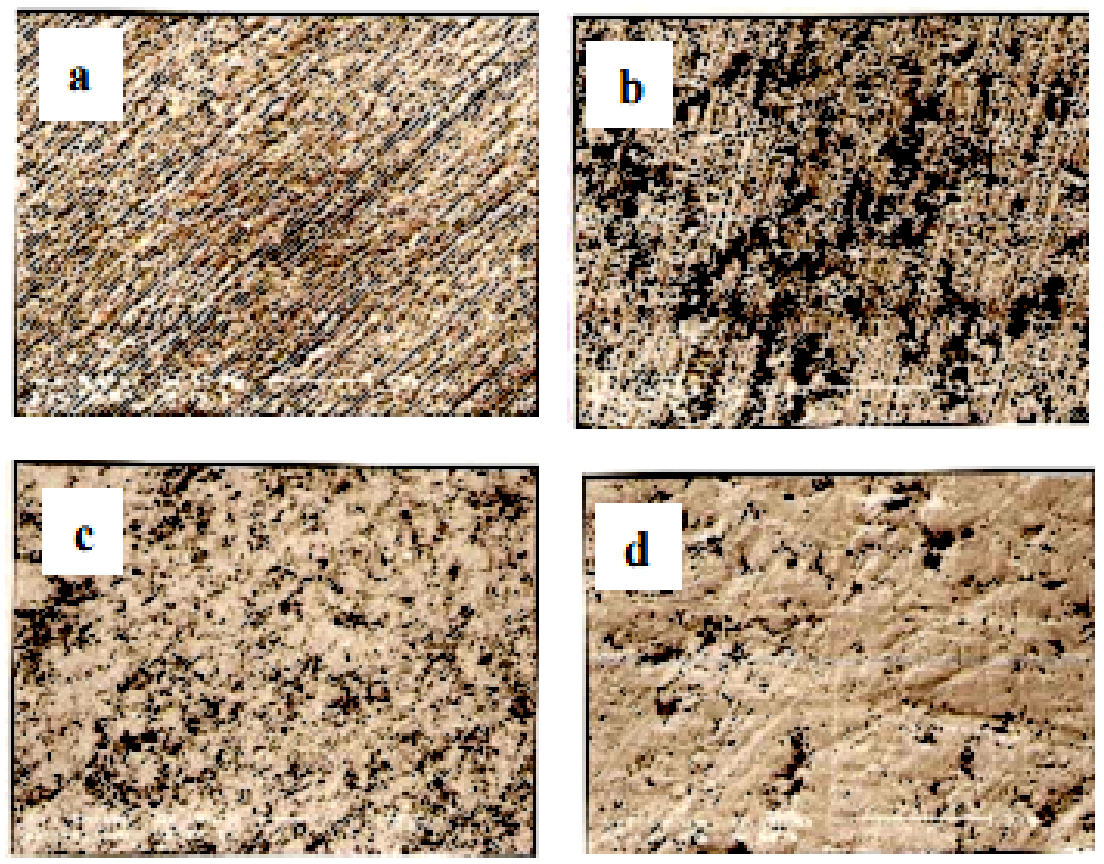

Figure 11. SEM photographs of aluminium sample, (a) before immersion, (b) after corrosion, (c) in presence of $4 \% \mathrm{v} / \mathrm{v}$ Aloe extract(low concentration) and (d) in presence of 48\% v/v of Aloe extract (high concentration) in $0.5 \mathrm{M} \mathrm{HCl}$ solution at $30^{\circ} \mathrm{C}$.
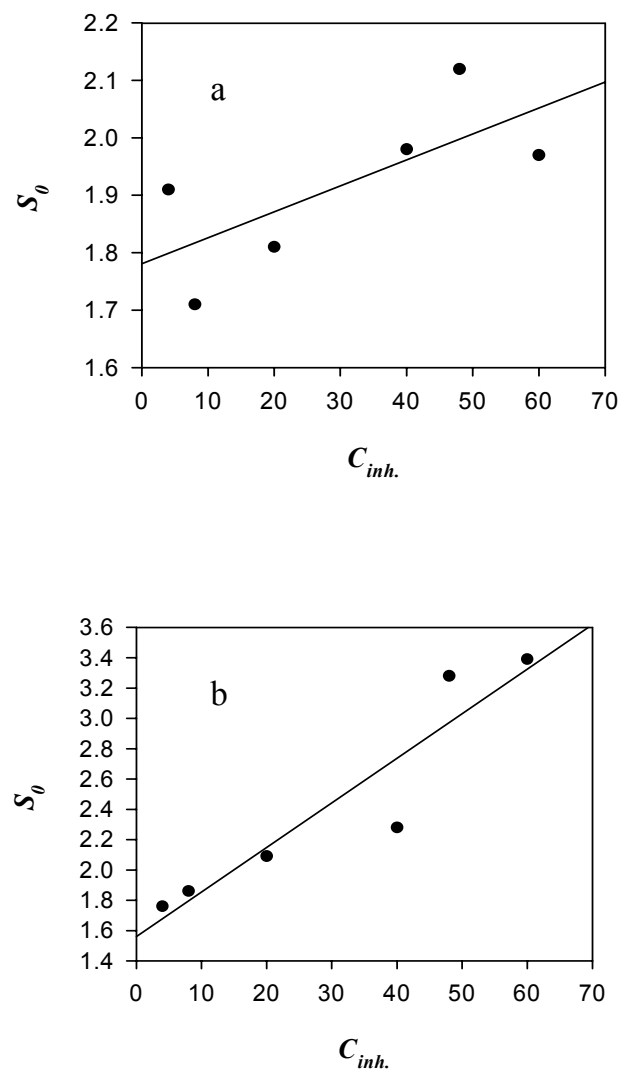

Figure 12. The relation between Cinh. and $\mathrm{S}$ for the corrosion of $\mathrm{Al}$ sample in $0.5 \mathrm{M} \mathrm{HCl}$ in presence of different concentrations of Aloe extract $+0.01 \mathrm{M} \mathrm{NaI}$ at $30^{\circ} \mathrm{C}$ from (a) polarization, (b) impedance . 

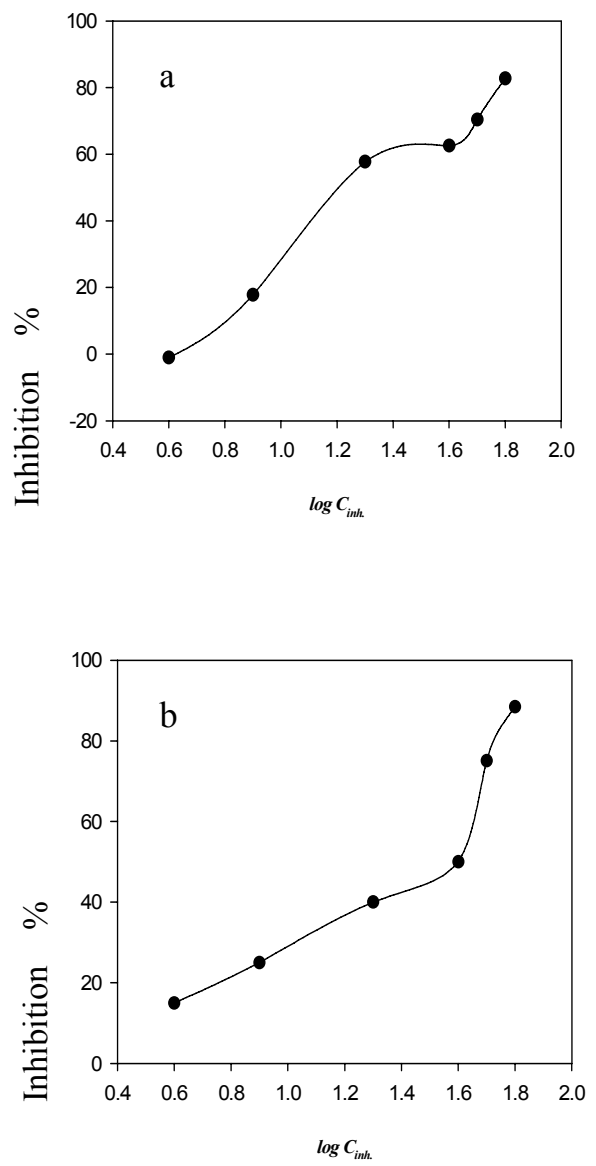

Figure 13. The relation between $\log \mathrm{C}_{\mathrm{inh}}$ and Inhibitiony efficiency for the corrosion of $\mathrm{Al}$ sample in $0.5 \mathrm{M} \mathrm{HCl}$ in presence of different concentrations of Aloe extract $+0.01 \mathrm{M} \mathrm{NaI}$ at $30^{\circ} \mathrm{C}$ from (a) polarization, (b) impedance.

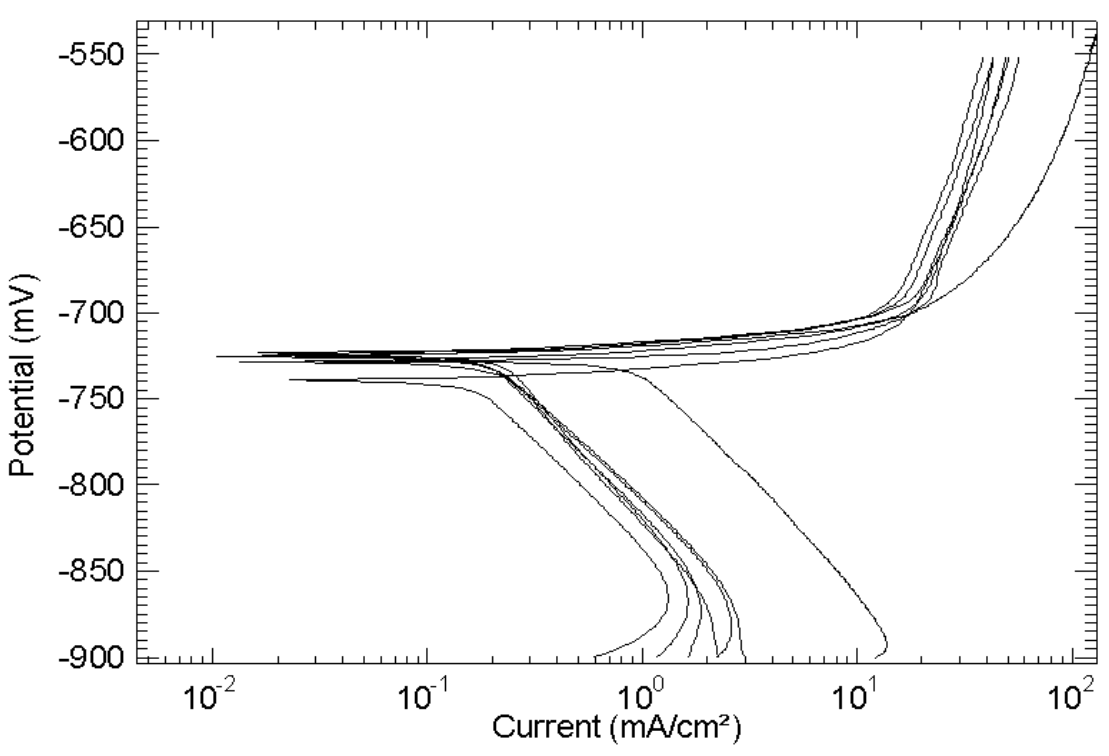

[(F) 0.00 (1) $1.0 \times 10^{-4}$ (2) $2.5 \times 10^{-3}$ (3) $1.0 \times 10^{-2}$ (4) $2.5 \times 10^{-2}$ (5) $3.0 \times 10^{-2}$ (6) $\left.5.0 \times 10^{-2}\right] \mathbf{~ M ~}$

Figure 14. Polarization plot for $\mathrm{Al}$ sample corrosion in $0.5 \mathrm{M} \mathrm{HCl}+$ different concentrations of $\mathrm{NaI}$ and presence of $48 \% \mathrm{v} / \mathrm{v}$ of Aloe extract at $30^{\circ} \mathrm{C}$. 


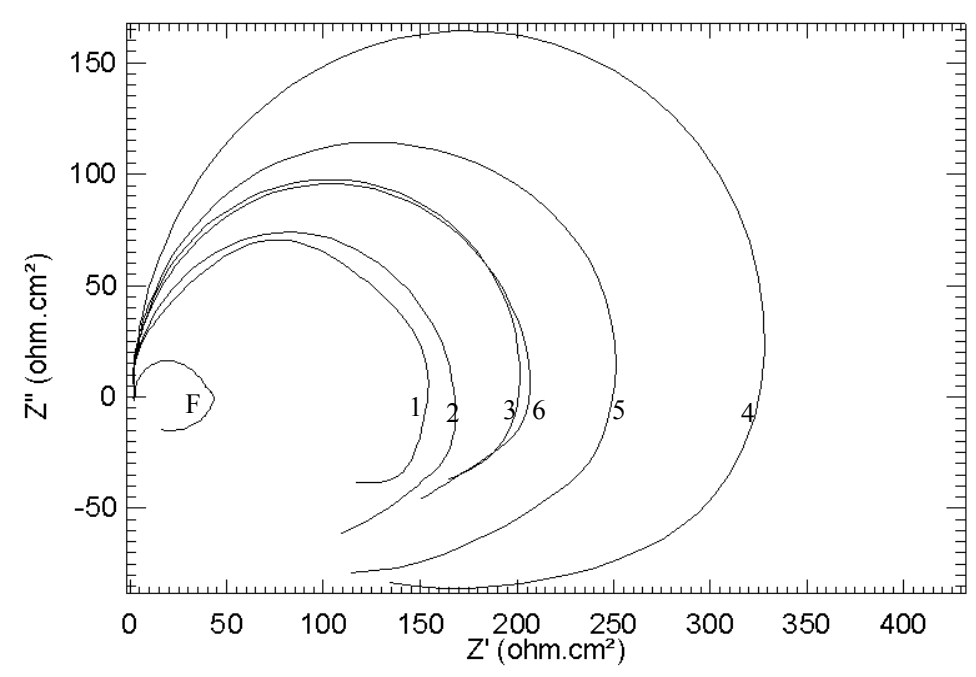

[(F) 0.00 (1) $1.0 \times 10^{-4}$ (2) $2.5 \times 10^{-3}$ (3) $1.0 \times 10^{-2}$ (4) $2.5 \times 10^{-2}$ (5) $3.0 \times 10^{-2}$ (6) $\left.5.0 \times 10^{-2}\right] \mathbf{~ M ~}$

Figure 15. Nyquist plot for $\mathrm{Al}$ sample corrosion in $0.5 \mathrm{M} \mathrm{HCl}+$ different concentrations of $\mathrm{NaI}$ and presence of $48 \% \mathrm{v} / \mathrm{v}$ of Aloe extract at $30^{\circ} \mathrm{C}$.
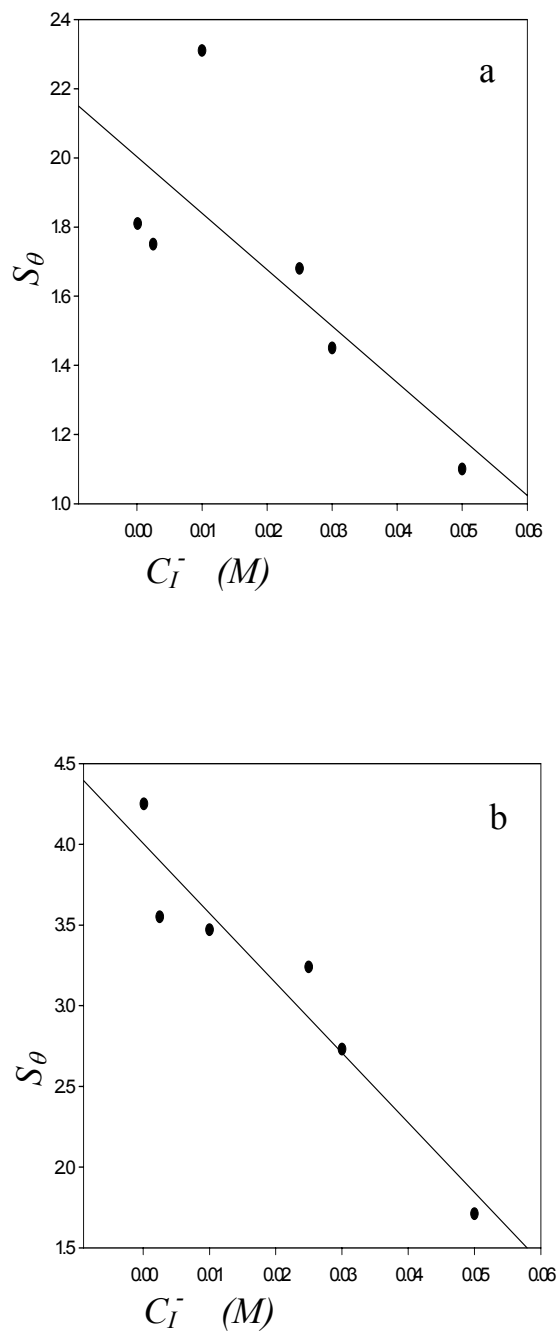

Figure 16. The relation between $\mathrm{C}_{\text {inh. }}$ and $\mathrm{S}$ for the corrosion of $\mathrm{Al}$ sample in $0.5 \mathrm{M} \mathrm{HCl}$ in of presence $48 \%$ of Aloe extract and different concentration NaI at $30 \mathrm{C}$ from (a) polarization, (b) impedance. 